\title{
From lavage to lipids: estimating diets of seabirds
}

\author{
Nina J. Karnovsky ${ }^{1, *}$, Keith A. Hobson ${ }^{2}$, Sara J. Iverson ${ }^{3}$ \\ ${ }^{1}$ Pomona College, Department of Biology, 175 W. 6th St., Claremont, California 91711, USA \\ ${ }^{2}$ Environment Canada, 11 Innovation Blvd., Saskatoon, Saskatchewan S7N 3H5, Canada \\ ${ }^{3}$ Dalhousie University, Department of Biology, 1355 Oxford St., Halifax, Nova Scotia B3H 4J1, Canada
}

\begin{abstract}
Understanding seabird marine habitat affinities, at-sea behavior, variability in reproductive success, migratory patterns, phenology, and other life history traits depends primarily on knowledge of the prey that they consume. Traditionally, estimating diets has been done through classification and enumeration of prey remains found in stomach contents of seabirds collected at sea, as well as chick meals, pellets, and feces collected at breeding colonies. These techniques have the advantage of high taxonomic resolution of prey, but suffer from biases due to the underestimation of soft-bodied or small prey that are digested completely and overestimation of prey with durable parts that are retained for long periods of time. Recent innovations in 2 biochemical assays of seabird tissues - stable isotope and fatty acid analyses - have greatly expanded knowledge of seabird diets and have advanced our understanding of the ways in which seabirds can indicate inter-seasonal, annual, decadal, and longer shifts in oceanographic conditions over varying spatial scales. Advances in statistical approaches to these data have provided new ways in which prey can be identified and quantified. When applied in combination, these 3 techniques (traditional diet sampling, and stable isotope and fatty acid analyses) have the potential to reveal pathways of energy flux across marine ecosystems and to provide new insight into marine ecosystem dynamics. We review the basic principles of these approaches to determining seabird diet and emphasize the need for more formal conceptual and statistical integration of methods to advance this field.
\end{abstract}

KEY WORDS: Diet - Seabird · Stable isotope $\cdot$ Isoscape $\cdot$ Mixing models $\cdot$ Bayesian $\cdot$ Quantitative fatty acid signature analysis · QFASA

\section{INTRODUCTION}

Diet forms the critical link between seabirds and the biotic and abiotic components of their environment. Linking variability in oceanographic conditions with the array of measurements we make on seabirds (e.g. reproductive success, chick growth rates, recruitment, survival, at-sea distributions, diving behavior, stress levels, energetic expenditures, body condition, phenology) requires understanding the type, amount, and quality of prey that seabirds consume. Furthermore, a profound understanding of seabird diets is critical to the conservation of these marine top predators. Assessment of seabird diets can elucidate factors causing population declines (e.g. Becker \& Beissinger 2006) and can identify par- ticular prey (e.g. Cury et al. 2011) or foraging areas (e.g. Louzao et al. 2011) that need protection.

Traditionally, estimating diets has been done through collection of ingested prey when seabirds are at breeding colonies. This technique can reveal the type and number of prey, but can be biased towards prey with durable parts. Biochemical assays of seabird tissues such as stable isotope (Hobson et al. 1994) and fatty acid (FA) signature analysis (Iverson et al. 2007) have provided insight into trophic levels of diet, how diets shift over time (e.g. diets during winter when seabirds are often inaccessible) and regions (e.g. benthic versus pelagic, and specific migratory routes), and have elucidated differences between adult and chick diets (Hobson 1993, Hobson et al. 2002a,b, Karnovsky et al. 2008). However, these biochemical 
approaches are limited in their ability to assess prey type and the quantity of prey consumed when diverse prey from similar trophic levels or with similar FA compositions are eaten. Nevertheless, the careful quantification of stomach contents in conjunction with these biochemical techniques has advanced our understanding of the ways in which seabirds can indicate inter-seasonal, annual, decadal, and longer shifts in oceanographic conditions and over varying spatial scales. These innovations in assessing diets are expanding the types of questions that can now be answered. Integration of these approaches is the next frontier in evaluating seabird life history.

\section{TRADITIONAL METHODS}

\section{Background}

Traditional assessment of seabird diets at colonies usually involves the identification and enumeration of prey found in stomachs, regurgitates, feces, pellets, and gular pouches, or observations of food provisioned to chicks (see Duffy \& Jackson 1986, Barrett et al. 2007). Here we describe the techniques briefly with an emphasis on the limitations and recent innovations of each method.

Measurements of diets using traditional diet sampling techniques reflect the food ingested over short time scales (hours to days) prior to sampling (e.g. Karnovsky et al. 2003). Furthermore, diet sampling at the colony is usually restricted to the spring or summer, which is the chick-rearing period when adults return to land (e.g. Cherel et al. 2002) and prey delivered to chicks could differ from those ingested by adults (e.g. Shealer 1998).

Biases in this method stem from the rapid digestion of some types of prey and the retention of other types of prey or hard parts. Soft-bodied prey are often digested rapidly and are underestimated (e.g. Polito et al. 2011). Furthermore, some species of seabirds that have gizzards retain hard parts such as squid beaks for extended periods (Furness et al. 1984). Another complication is that retention may not be complete, and numbers of squid can be over- or underestimated depending on the part of the squid beak (upper or lower beak) used in estimating the number of squid consumed (Xavier et al. 2011). Prey that have small or fragile hard parts are often excreted or digested completely and are therefore underestimated (Van Heezik \& Seddon 1989, Xavier et al. 2011). Even though fish otoliths resist digestion because they are made of an aragonite form of calcium carbonate and otoline (Gon \& Heemstra 1990), small otoliths can be digested completely. In a study of captive little penguins Eudyptula minor, Gales (1988) found that otolith length and weight decreased as the resident time in the penguin increased. Van Heezik \& Seddon (1989) found that smaller otoliths were digested faster in yellow-eyed penguins Megadyptes antipodes. Thus, fish that have small otoliths can be underestimated in diets. However, careful attention to these biases can reveal much about the foraging strategies of seabirds. For example, Spear et al. (2007) recorded stomach fullness, differential digestion of prey, and levels of erosion of otoliths and squid beaks found in seabird stomachs. They used this to reveal which seabirds fed nocturnally, the previous day, within the study area, scavenged, or fed in association with subsurface predators (Spear et al. 2007).

\section{Direct observation}

Diet sampling at the breeding colony usually occurs during the breeding season when seabirds return regularly to feed their growing chicks. From early on, researchers took advantage of the fact that some species carry prey in their bill. Prey can be identified, the size can be estimated, and the frequency of delivery to chicks is easily observed. Pearson (1968) elucidated the ecological differences amongst 3 species of terns in this manner. Long-term observations of birds at the same colony can reveal inter-annual shifts in the prey base around the colony. For example, Gaston et al. (2003) observed the fish carried back to chicks by thick-billed murres Uria lomvia from 1980 to 2002. They observed a shift from ice-dependent Arctic cod Boreogadus saida to more boreal species, which was coincident with the decline in ice around the colony. Several technological innovations have increased the efficiency and accuracy of collecting these data. For example, Larson \& Craig (2006) used 'digiscoping' (the use of a digital camera held up to spotting scopes or binoculars) to photograph terns returning with fish in their bills. These digital photographs allowed them to estimate size more accurately and identify the prey and to more easily confer with fish biologists on fish identification. These data showed that the terns took a greater diversity of fish than previously known. All manner of handheld digital recording devices have been employed to aid in the recording of observations of food delivery at colonies. For example, as part of a long-term study of common murres $U$. aalge on the Farallones Islands, California, USA, biologists record 
the fish size and species as well as bird identity (from bands and known nest sites) with hand-held electronic recorders (Palm Pilot; R. Bradley pers. comm.), and digital programs are now available for multiple device types (e.g. HanDbase4, DDH Software).

\section{Analysis of pellets}

Some seabirds regurgitate pellets containing the undigested hard parts of the prey they consumed. Collection of pellets is a non-invasive way of assessing diets (e.g. Duffy \& Laurenson 1983). Harris \& Wanless (1992) analyzed the otoliths from pellets of European shags Phalacrocorax aristotelis and found that they relied on an unexpected food source, lesser sandeels Ammodytes marinus. A major drawback of using pellets is possible bias. Lindsay \& Meathrel (2008) recorded partially consumed prey and the prey identified in pellets of Pacific gulls Larus pacificus at several colonies. They found that their estimates of prey consumption based on these indirect measures greatly underestimated the amount of prey consumed and were heavily biased towards the large prey that had hard parts. Nevertheless, using pellets alone, they were able to identify a wide range of prey species from diverse taxonomic groups (crabs, mussels, invertebrates, fish, and other seabirds).

\section{Gular pouch, regurgitates, and stomach lavage}

Some seabirds (e.g. little auks Alle alle) bring food back to their chicks in a sublingual gular pouch. These diet samples can be removed easily with a finger or a small spoon (e.g. Karnovsky et al. 2003). Other species readily regurgitate upon capture (e.g. Cassin's auklet Ptychoramphus aleuticus and thinbilled prion Pachyptila belcheri), which can then be collected (e.g. Abraham \& Sydeman 2006, Quillfeldt et al. 2010). Still others swallow their prey into their stomachs (e.g. penguins, procellariforms, gulls). In his study of herring gulls Larus argentatus, Hunt (1972) found that voluntary regurgitations by chicks gave biased samples due to being incomplete. He found that by inserting his index finger into the proventriculus and scooping out the food, he was able to extract complete diet samples. In addition, these samples can be extracted through stomach lavage techniques (e.g. Ainley et al. 2003, Miller et al. 2009, Neves et al. 2011). Stomach lavage (also known as stomach flushing or water offloading) involves the introduction of saltwater into the stomach of the bird with a tube and then flushing out the contents of the stomach (Wilson 1984). Stomach lavage has greatly expanded the understanding of diets of seabirds that regurgitate food back to chicks and is a great advance over killing birds to examine their stomach contents (e.g. Volkman et al. 1980) or the use of emetics (Jablonski 1985). While impacts of stomach lavage may vary with different species, Robertson et al. (1994) found that Adélie penguin Pygoscelis adeliae adults did not alter their foraging behavior after flushing, and their chicks grew normally.

\section{Analysis of guano}

Hard parts such as otoliths and squid beaks are often excreted by seabirds. By sorting through guano, these can be extracted, identified, and measured, and the fish and squid component of the diets can be assessed. Because these hard parts can accumulate in the colony over time, long-term diet shifts can be assessed if different layers of the ornithogenic soil can be dated. McDaniel \& Emslie (2002) were able to assess changes in diets of Adélie penguins over $6000 \mathrm{yr}$ by measuring otoliths and squid beaks recovered from different layers of Adélie penguin colonies. Genetic analysis of guano has begun to be used to identify seabird prey. For example, the seasonal transition from krill diets to myctophids was detected in the DNA found in macaroni penguin Eudyptes chrysolophus guano (Deagle et al. 2007). Despite the appeal of this non-invasive technique, several challenges remain; there is often very little amplifiable DNA in guano, and clone libraries of specific primers of prey species are currently lacking (Deagle et al. 2007). Analysis of fecal DNA from captive little penguins fed known diets revealed that each fish species undergoes differential digestion, which influences detection in excreted DNA (Deagle et al. 2010). However, Deagle et al. (2010) found that digestion rates were constant across individuals, so there is potential for correction factors to be developed to estimate quantities of different prey consumed using this technique.

\section{Taxonomy}

One of the strengths of traditional diet sampling is the provision of taxonomic content of the diets examined. However, identifying the prey that are recovered or observed with traditional diet sampling techniques often requires extensive knowledge of the taxonomy of prey species. As prey are often partially 
digested, this requires knowledge of diagnostic fragments (e.g. Quillfeldt et al. 2010). Field guides of many components of seabird prey, such as fish bones and squid beaks, are available (e.g. Hecht 1987, Hansel et al. 1988, Xavier \& Cherel 2009). The ability to view and measure prey seen through the microscope on a computer screen allows researchers to save images and electronically send them to experts (Reinalda et al. 2010). However, access to taxonomists is often the limiting factor in prey species identification. Worldwide, there has been a decline in the number of trained taxonomists (Pearson et al. 2011).

\section{Measurements}

Stomach contents are often characterized by 2 measures, percent occurrence and average percent of total contents. Percent occurrence reflects the frequency with which birds consumed a particular taxon. Average percent of total reflects the average numerical proportion of each taxon. Another commonly used measure is percent biomass based on wet weight measurements (e.g. Cherel et al. 2002). Hard parts such as otoliths, squid beaks, and bones provide identifiable remains and can be included in the percent occurrence and average percent total measurements but often make up a small fraction of the wet weight of the prey in the stomach sample. In some cases, it is possible to use regressions of prey morphometrics to infer the original size and mass of the fish or squid consumed (e.g. Cherel et al. 2002).

Diet studies in which comparisons are made among stomach contents have benefitted enormously from the application of statistical techniques that allow for group comparisons. Principal component analysis (PCA) in conjunction with ANOVA allows the identification of statistically significant differences amongst groups (e.g. Fig. 1, see also Spear et al. 2007). Distance measures such as multi-dimensional scaling and cluster analyses provide evidence of which groups have more similar diets (e.g. Fig. 2). These techniques can utilize frequency of occurrence, average percent of total, or prey biomass data.

\section{Future directions}

Despite the biases in traditional diet sampling, application of these techniques is the only way that specific taxonomic information can be known. Collecting samples can often be done with minimal disturbance to the birds (gular pouch contents, pellets, direct observations). Therefore, even with known limitations, consistent application of traditional sampling techniques can provide critical information when comparing spatial, temporal, and demographic effects on diet. Recommendations to advance the use of these techniques include:

(1) Producing photographs and field guides of type specimens, and sharing these data freely to make the specialized knowledge of taxonomists more readily applicable. For example, the work by Xavier \& Cherel (2009) is available without charge from the British Antarctic Survey.

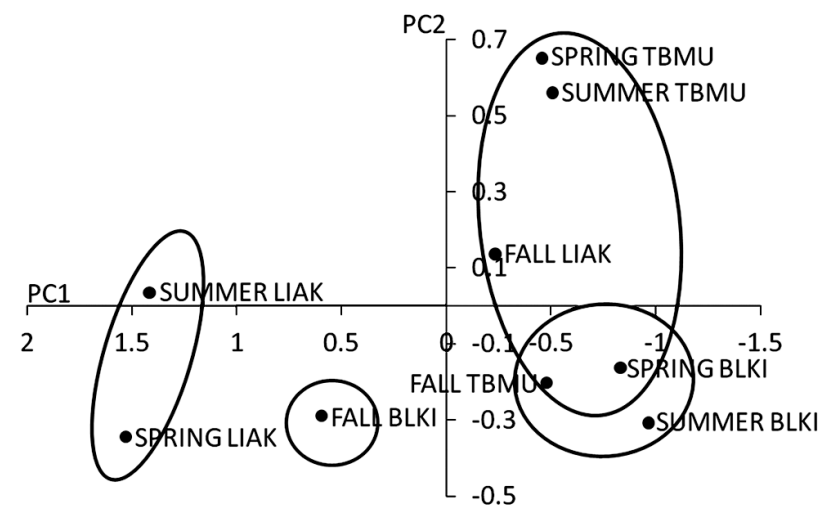

Fig. 1. Principal component analysis (PCA) comparing percent occurrence of prey among 8 combinations of seasons/ species of seabirds foraging in the North Water Polynya. Prey composition of species groups enclosed in the same circle were not significantly different (Sidak multiple comparison tests, p > 0.05) BLKI: black-legged kittiwake Rissa tridactyla; TBMU: thick-billed murre Uria lomvia; LIAK: little auk Alle alle (Karnovsky et al. unpubl.). Based on data presented by Karnovsky et al. (2008)

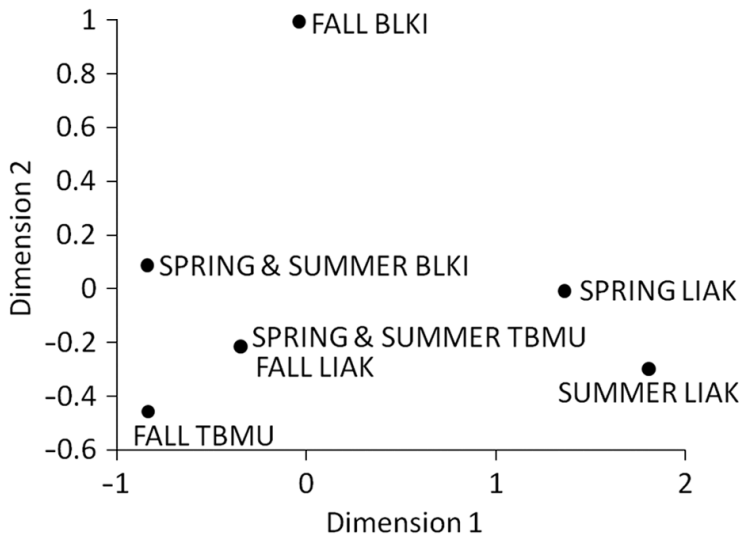

Fig. 2. Multi-dimensional scaling (MDS) plot based on the distance matrix derived from a cluster analysis of the percent frequency occurrence of prey that were eaten by the same species/seasons as in Fig. 1 (Karnovsky \& Hunt unpubl.). Based on data presented by Karnovsky et al. (2008) 
(2) Collection and archiving of prey voucher specimens. Many regressions for mass and length of fish are based on very few fish specimens. Furthermore, there are still many fish and squid whose otoliths and beaks are undescribed.

(3) Continued development of the identification of prey from DNA in feces.

\section{STABLE ISOTOPES}

\section{Background}

From the earliest isotopic analyses of seabird tissues over 20 yr ago (Hobson 1987, Schaffner \& Swart 1991), researchers have embraced this approach to decipher the nutritional ecology of seabirds. There has been an exponential increase in the use of such measurements using a variety of seabird and prey tissues, ranging from temperate (Bearhop et al. 2000, Hipfner et al. 2010) to tropical (Awkerman et al. 2007, Cherel et al. 2008) and polar regions (Hodum \& Hobson 2000, Hobson et al. 2002a,b, Quillfeldt et al. 2010, Phillips et al. 2011). These investigations followed from earlier use of isotopic analyses of marine systems (Owens 1987, reviewed by Michener \& Schell 1994). Several authors have provided overviews of the use of stable isotope methods in seabird investigations (Forero \& Hobson 2003, Barrett et al. 2007, Bond \& Jones 2009) or more general use of stable isotope techniques in avian or mammalian ecology (Inger \& Bearhop 2008, Tollit et al. 2010, Hobson 2011). Here we focus on recent developments and future directions emerging in this rapidly changing field of study.

The primary use of stable isotopes in seabird ecological studies has been the establishment of trophic position and region of feeding (e.g. Fig. 3). These efforts, for the most part, have been based on the measurement of $\delta^{15} \mathrm{~N}$ and $\delta^{13} \mathrm{C}$ values of seabirds and their prey, and are based on the documented isotopic discrimination between diet and seabird tissues and knowledge of baseline isotopic signatures in the inshore and pelagic foodwebs used by birds (reviewed by Bond \& Jones 2009). Isotopes of a variety of other elements (e.g. O, H, S, Hg, Pb, Sr) can be used effectively in marine systems, especially as additional tracers of source inputs, but these applications are still relatively infrequent (Rubenstein \& Hobson 2004, Hobson 2011). More recently, isotopic measurements have been used to infer migratory movements, connectivity, and seasonal interactions based largely on increasing delineation of marine isoscapes or spatial patterns in foodweb isotopic signatures across the oceans (West et al. 2010). Increased use of captive seabirds raised on known or manipulated isotopic diets has also provided new insights into the role of physiology and growth on isotopic values in seabird tissues and into mechanisms controlling the behavior of isotopes in vivo (Williams et al. 2007). The recent development of isotopic mixing models based on Bayesian techniques has contributed greatly to more robust estimates of dietary inputs that better propagate known sources of error (Parnell et al. 2010).

\section{Trophic level (TL) and source of feeding}

The placement of individuals or populations to trophic level (TL) using stable isotopes is possible because the assimilation of elements from one TL to another involves a reasonably predictable change in the ratio of heavier to lighter isotopes for several elements. This is due to a variety of physiological processes that ultimately involve rate-limiting steps. Thus, the identification of these tissue- and elementspecific isotopic discrimination factors is fundamental to the application of the approach. The conversion

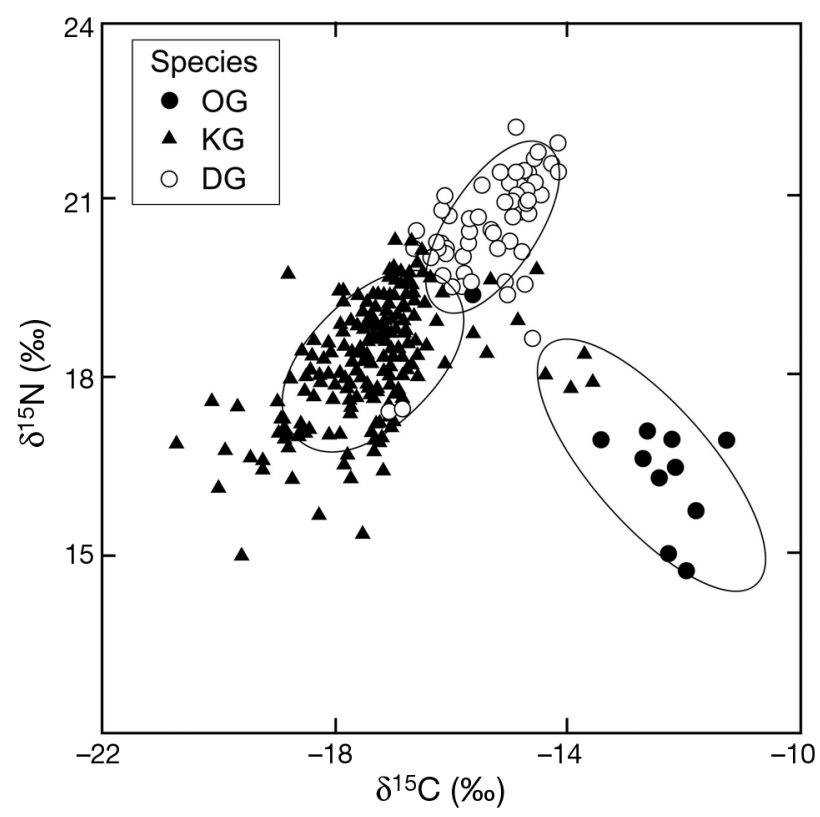

Fig. 3. Larus atlanticus, L. dominicanus, and Leucophaeus scoresbii. Isotopic segregation of 3 sympatric large gulls from coastal Patagonia, Argentina. OG: Olrog's gull, KG: kelp gull, DG: dolphin gull. The figure illustrates the power of the isotope approach for delineation of communities related to trophic positions and relative use of benthic vs. pelagic feeding. Gaussian bivariate ellipses based on whole blood of chicks (after Forero et al. 2004) 
of isotope data to actual TL depends upon the assumption that we know enough about the isotopic composition of primary producers (i.e. phytoplankton) at the base of the foodweb of interest, or that we can identify a key organism in the foodweb of interest whose TL and isotopic value are known. Thus, if primary producers are considered, we have

$$
\mathrm{TL}_{\mathrm{c}}=1+\left(\delta \mathrm{X}_{\mathrm{c}}-\delta \mathrm{X}_{\mathrm{p}}\right) / \Delta \mathrm{TL}
$$

where $\mathrm{TL}_{\mathrm{c}}$ is the TL of the consumer of interest, $\delta \mathrm{X}_{\mathrm{c}}$ is the isotopic composition of the consumer, $\delta \mathrm{X}_{\mathrm{p}}$ is the isotopic composition of primary producers, and $\Delta \mathrm{TL}$ is the average tissue-specific isotopic discrimination factor between TLs for the marine foodweb of interest. The problem is that we rarely, if ever, are able to derive an accurate estimate of $\delta \mathrm{X}_{\mathrm{p}}$. This is because we usually sample particulate organic matter rather than 'pure' phytoplankton. Also, we know that the isotopic composition of phytoplankton can change throughout the season depending on sea surface temperature and nutrient availability (Michener \& Schell 1994, Montoya 2007).

A more practical approach has been to assume that we can anchor a foodweb to an organism whose TL is assumed to change little, such as an herbivorous copepod or any organism at TL 2. In such cases, we have:

$$
\mathrm{TL}_{\mathrm{c}}=2+\left(\delta \mathrm{X}_{\mathrm{c}}-\delta \mathrm{X}_{\mathrm{h}}\right) / \Delta \mathrm{TL}
$$

where $\delta \mathrm{X}_{\mathrm{h}}$ is the isotopic composition of the obligate herbivore chosen. However, even in this case, many 'herbivorous' zooplankton also ingest micro-zooplankton, thereby blurring the boundaries between strict herbivores and primary carnivores from an isotopic perspective.

The first generation of seabird dietary investigations using stable isotopes to determine TL relied heavily on these models (Hobson \& Welch 1992, Hobson 1993, Hobson et al. 1994, Forero et al. 2004, Hedd \& Montevecchi 2006). This led to an interest in just how accurate estimates of isotopic discrimination values were.

Inferring TL and source of feeding from stable isotopes necessitates the use of an accurate diet-tissue isotopic discrimination factor (e.g. $\delta^{15} \mathrm{~N}, \delta^{13} \mathrm{C}$ ). Dietary models are based on the application of such discrimination factors between diet and consumer tissues in a simple arithmetic manner, and sensitivity analyses have shown the problems that can arise if inappropriate discrimination factors are assumed (Caut et al. 2008a). Fortunately, meta-analyses of data based on captive studies across a broad range of taxa have provided reasonable estimates for a number of marine applications (Kelly 2000, Post 2002) and have revealed patterns associated with metabolic pathways of voiding nitrogenous waste (Vanderklift \& Ponsard 2003). Bond \& Jones (2009) provided a summary of the $\delta^{15} \mathrm{~N}$ and $\delta^{13} \mathrm{C}$ estimates derived from captive studies on a variety of tissues (e.g. blood and feathers). Evans Ogden et al. (2004) provided similar estimates for a marine-associated shorebird, and Polito et al. (2009) reviewed isotopic discrimination factors associated with seabird egg components.

Recent studies have emphasized the importance of dietary quality and quantity in driving isotopic discrimination in animals, especially for $\mathrm{N}$ (Robbins et al. 2005, Martínez del Rio et al. 2009). These studies suggest that high-quality diets, namely those providing the most limiting amino acid (AA), result in lower $\delta^{15} \mathrm{~N}$ values, and attempts have been made to provide calibration algorithms relating $\delta^{15} \mathrm{~N}$ to diet quality (Robbins et al. 2005, see also Caut et al. 2008b). These corrections may be useful for omnivores that have access to a wide range of diets of varying $\mathrm{N}$ content. However, seabirds feeding on marine sources of protein (invertebrates, fish, mammals, birds) almost certainly meet their $\mathrm{N}$ requirements adequately through these sources, and we predict only relatively small effects of diet quality on seabird isotopic discrimination. Thus, for seabirds, more interest has been aimed at how other factors may influence $\delta^{15} \mathrm{~N}$ and $\delta^{13} \mathrm{C}$, such as the effects of growth rate and dietary intake in chicks versus adults, nutritional stress, and aspects of metabolic routing also common to other taxa.

Severe catabolism of body proteins, typical of fasting or starvation, increases $\delta^{15} \mathrm{~N}$ values in a variety of bird tissues (Hobson et al. 1993), and individuals that have been salvaged from wrecks or oil spills are not suitable for dietary reconstructions, especially those involving metabolically active tissues (Sanpera et al. 2008). For healthy wild birds, contrasting diets of provisioning adults and chicks using stable isotope assays has provided information on adult diets as well as those of more easily sampled chicks. Using captive or controlled studies of wild alcids, Williams et al. (2007) and Sears et al. (2009) demonstrated that growth rate and amount of food intake of young can affect tissue $\delta^{15} \mathrm{~N}$ values, independent of diet $\delta^{15} \mathrm{~N}$ value. While this effect was relatively small (up to $0.7 \%$ in $\delta^{15} \mathrm{~N}$ and $\sim 0.3 \%$ in $\delta^{13} \mathrm{C}$ ), it does reveal potential sources of variance in isotope ratios of chicks in wild populations. These authors suggested that the depletion in tissue $\delta^{15} \mathrm{~N}$ values with growth rate and reduced dietary intake was due to an increase in $\mathrm{N}$ use efficiency. Thus, isotopic conse- 
quences of protein catabolism in fasting birds seems to be opposite to the effect of more subtle and likely more natural variation in nutrition and growth experienced by chicks. We also know that growing chicks will typically have more urea in blood plasma than adults and that this might depress chick blood $\delta^{15} \mathrm{~N}$ values (Bearhop et al. 2002). Together, such agerelated effects on chick tissue $\delta^{15} \mathrm{~N}$ values are likely to bias chick values to be lower than those of adults with the same diet. Woo et al. (2008) found no dietary difference between chicks and adult thick-billed murres Uria lomvia at a low Arctic colony based on similar blood $\delta^{15} \mathrm{~N}$ values, a conclusion that may need to be revisited.

\section{Isotopic turnover}

Elemental or isotopic turnover determines the period of integration over which diets contribute to tissue synthesis. In most dietary studies, we assume that an organism is in equilibrium with its diet or local food web, but this may or not be the case, depending on the movement history of the individual and the tissue chosen. The most useful estimates of tissue turnover have been provided by captive experiments in which birds have been switched from one diet to an isotopically different diet, and patterns of isotopic change in the tissue of interest are recorded. The resulting patterns of isotopic change in tissues fit an exponential decay model, and so the half life of a given element in a tissue can be readily derived (Hobson \& Clark 1992). More recently the derived parameter, residency time of an element in tissue, has been used (Martínez del Rio \& Anderson-Sprecher 2008). For most avian applications, we have a reasonably good idea of these turnover rates for most tissues of interest, such as blood plasma, blood cells, whole blood, muscle, and liver. Both growth and catabolic components of tissue turnover rates follow an allometric relationship, which allows extrapolation to species of different body mass (Carleton \& Martínez del Rio 2005, Martínez del Rio et al. 2009). Seabird researchers can thus estimate isotopic turnover rates for their species and tissue of interest, although further controlled studies using species of various sizes are still needed.

A major recent development in our understanding of isotopic turnover in animals has been provided by the application of graphical methods previously designed to trace inputs from individual radionuclides to a mixture. Using this approach, Cerling et al. (2007) demonstrated that turnover patterns can be the result of combined fast and slow turnover pools. This approach promises greater insight into the physiology of birds in general and metabolic routing in particular. Further captive diet-switch experiments that examine origins of specific dietary or endogenous proteins and their relative rates of incorporation into tissues will be the next generation of turnover experiments.

\section{Mixing models}

In cases where the isotopic composition of dietary alternatives is known, isotopic mixing models can be used to estimate the relative proportion that each contributes to consumers. The key parameter in such models is the diet-tissue discrimination factor for each isotope used in the model. Currently, the major weakness of dietary isotope models is their assumption of perfect mixing of dietary elements. Dietary macronutrients undergo differential routing, but mixing models do not automatically consider this. This is a particular weakness of dealing with bulk tissues rather than individual compounds. Thus the $\delta^{15} \mathrm{~N}$ axis really represents a 'protein axis,' since $\mathrm{N}$ only occurs in dietary protein and $\mathrm{N}$ atoms end up in proteins in the consumer. In marine systems, the $\delta^{13} \mathrm{C}$ axis, however, can be more difficult to interpret if $\mathrm{C}$ in dietary lipids contributes to consumer proteins and lipids. Typically, lipids are removed before bulk tissue analyses and are dealt with in separate pathways (Cherry et al. 2011). Procellariform seabirds that feed their young prey stomach oils may be a special case involving much greater transfer of lipid carbon to body tissues and so may require special consideration when applying stable isotope methods (Thompson et al. 2000, Cherel et al. 2005).

A major breakthrough in the way animal ecologists deal with isotope mixing models was provided by a probabilistic approach where there are more isotopically distinct dietary sources than isotopes to provide a unique mathematical solution (i.e. when the number of sources exceeds the number of isotopes by $>1$ ). This allowed ecologists to define ranges of possible solutions, information that can also be extremely valuable (Caut et al. 2008c). The pioneering work of Phillips \& Koch (2002) and Phillips \& Gregg (2003) in isotopic mixing models has been followed by Bayesian mixing models. A key advantage of these models is the ability to apply prior knowledge of diets, based on stomach content data, observation, or other means. In a Bayesian framework, the use of informed priors can greatly enhance our ability to 
accurately predict dietary contributions based on isotope data. In addition, recent models allow a much better means of dealing with error in dietary estimates, allowing error propagation and ultimately sensitivity analyses related to key parameters such as the diet-tissue isotope discrimination factor. Speciesand age-specific discrimination factors should be used whenever possible because inter- and intraspecific variations in these values can affect model results (Bond \& Diamond 2011). Currently, there are 3 primary (free) software products dealing with isotope-based mixing models. SIAR is based on $\mathrm{R}$ and allows for concentration-dependent mixing models (Parnell et al. 2010). MixSIR is based on Matlab but at least until recently did not allow a concentrationdependent option (Moore \& Semmens 2008). SISUS is an extremely user-friendly frequentist-based option (http://statacumen.com/sisus/). Seabird biologists are exploring the use of these mixing models to advantage (Votier et al. 2010, Polito et al. 2011).

\section{Isotopic niche}

With biplots of seabird tissue $\delta^{15} \mathrm{~N}$ versus $\delta^{13} \mathrm{C}$ (e.g. Fig. 3), differences in isotopic niche space can be seen. This approach can be extrapolated to multidimensional or multi-isotopic niche space (Bearhop et al. 2004, Newsome et al. 2007), and allows estimation of niche segregation or overlap among species, sexes, or age groups (e.g. Forero et al. 2002, 2005), and potentially, niche changes seasonally, spatially, or in response to changes in resource availability. This approach is also suited to study whether populations are comprised of specialists, generalists, or both (Bearhop et al. 2004, Layman et al. 2007, Woo et al. 2008). In well constrained systems (e.g. within an isotopically well defined and understood marine food web) and where all of the basic components of isotopic differences among individuals other than diet can be accounted for (molt phenology, isotopic discrimination factors, periods of isotopic integration), the isotopic niche concept remains interesting. However, there are assumptions that need to be emphasized in any such approach.

If 2 species, constrained to a given system, differ in their isotopic niche space, then it is likely that they also differ in their realized ecological niche space. However, if 2 species overlap, then it is less obvious that they occupy the same ecological niche because different dietary species (e.g. forage fish) can overlap extensively isotopically. The correct interpretation of isotopic niche changes thus requires a detailed knowledge of the isotopic nature of alternative dietary items and of how baseline isotopic patterns may change spatially. This remains a daunting challenge. A more parsimonious approach is to restrict attention to so-called 'trophic niches' using $\delta^{15} \mathrm{~N}$ measurements, as already discussed (e.g. Hedd et al. 2010), but again, researchers should always consider the possibility of variable $\delta^{15} \mathrm{~N}$ baselines in marine isoscapes (e.g. Jaeger et al. 2010b, Jaeger \& Cherel 2011). We suggest that seabird researchers more critically consider whether isotopic differences or similarities can always be translated to useful estimates of dietary or ecological niches.

\section{Marine isoscapes}

Stable isotope methods can be used to track movements of seabirds or to identify feeding regions, because marine food webs are not isotopically homogenous in space and time. This approach has been used in terrestrial systems (Hobson \& Wassenaar 2008, West et al. 2010) and more recently in marine systems (Fig. 4; Graham et al. 2010). Minami \& Ogi

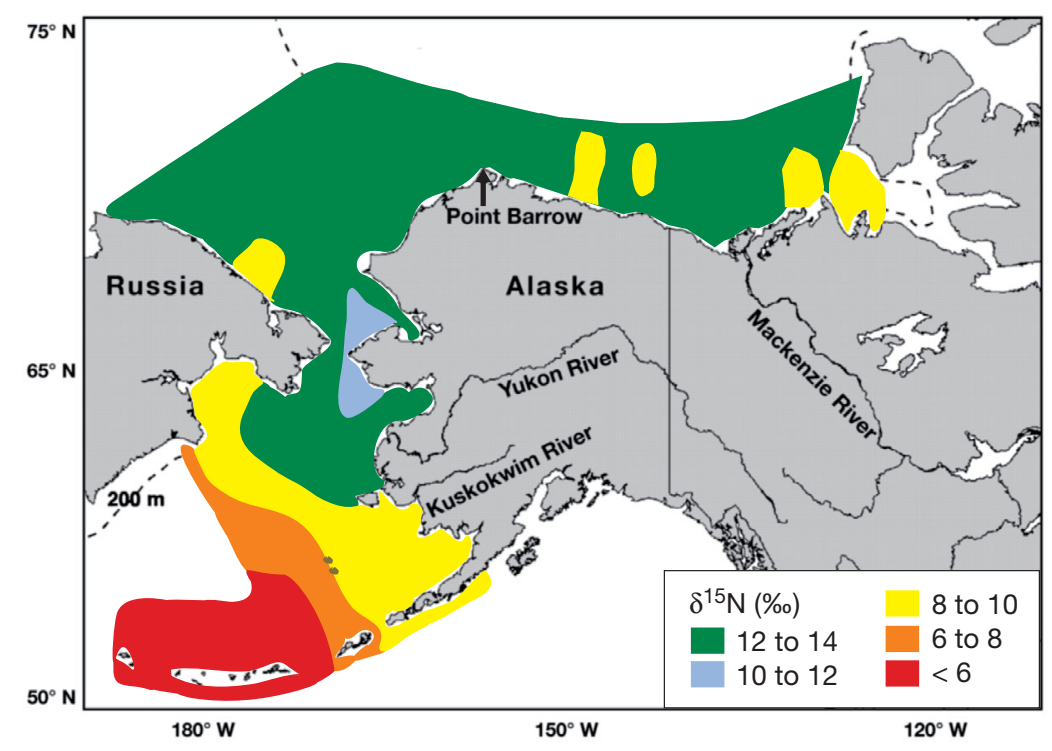

Fig. 4. $\delta^{15} \mathrm{~N}$ copepod isoscape of the Bering, Chukchi and Beaufort Seas illustrating the often highly structured isotopic nature of marine food webs, which can be used to delineate seabird origins. Isotopic structure must be considered when modeling trophic level over large regions (from Schell et al. 1998) 
(1997) were the first to explore this approach for seabirds by examining migratory dynamics in sooty shearwaters Puffinus griseus in the North Pacific. They noted that tissue $\delta^{15} \mathrm{~N}$ and $\delta^{13} \mathrm{C}$ muscle values of immature shearwaters changed in time and space, and they associated these patterns to regions of the Pacific with areas of upwelling that were consistent with the migratory behavior of this species. More recently, the strong isotopic structure of marine food webs in the Southern Ocean, which show pronounced depletion especially in ${ }^{13} \mathrm{C}$ with latitude, has informed the analysis of movements of several species of seabirds once they departed from colonies (Quillfeldt et al. 2005, 2008, 2010, Cherel \& Hobson 2007, Phillips et al. 2009, Roscales et al. 2011). For Cory's shearwater Calonectris diomedea diomedea breeding in the Mediterranean, Ramos et al. (2009a) provided an analysis of $\delta^{15} \mathrm{~N}, \delta^{13} \mathrm{C}$, and $\delta^{34} \mathrm{~S}$ in flight feathers to reveal a spatiotemporal gradient in molt sequence which could ultimately be related to movements off western Africa during the non-breeding season.

The placement of individual seabirds to geographic regions using marine isoscapes in the absence of known persistent and major isotopic gradients remains a daunting task. However, recent research is encouraging. Stable-C isotope values in primary production are sensitive to ambient water temperature, and $\delta^{13} \mathrm{C}$ values in tissues of sessile and migratory marine animals are well correlated with sea surface temperatures (Barnes et al. 2009, MacKenzie et al. 2011). This creates the possibility of producing year-specific marine isoscapes based on remotely-sensed water temperature. As our understanding of key mechanisms controlling the isotopic composition of primary productivity increases, our ability to construct marine isoscapes relevant to seabird studies will increase (Graham et al. 2010, Barnes et al. 2011). Finally, the combination of several assays in addition to tissue isotope values of consumers can result in greater resolution of placement. This was demonstrated by Gómez-Díaz \& González-Solís (2007), who combined morphological, genetic, stable isotope, and trace element analyses to assign a suite of pelagic seabirds to origin.

Our ability to link stable isotope values with locations of birds at sea has been greatly enhanced by the recent development of spatial tracking devices such as geolocators (e.g. Jaeger et al. 2010b) or GPS tags (e.g. Votier et al. 2010). These devices provide information on movement patterns during the nonbreeding season, as the birds move to isotopically distinct regions while they sequentially replace their feathers (e.g. González-Solís et al. 2011). Shorterterm movements during foraging trips in the breeding season can be assessed with the combined use of tracking devices and stable isotope analysis of a tissue with shorter turnover such as blood (e.g. Rayner et al. 2010). However, regional marine isoscapes may not show sufficient structure over regions of interest to assign foraging locations. For example, seabirds breeding in the NE Atlantic did not show regionalscale biogeographic differences in stable isotope values despite inter-colony variation in feeding locations (Roscales et al. 2011). A major challenge in using tracked seabirds as a means of describing marine isoscapes is the fact that it is still difficult to tease out the isotopic effects of changes in diet and changes in baseline isotope values.

\section{Compound-specific approaches}

The vast majority of stable isotope investigations in ecological studies have used the isotopic measurement of bulk tissues (e.g. feather keratin, muscle, lipids, blood). Increasingly, there is interest in the isotopic composition of individual compounds such as AAs or FAs, which can now be measured through gas chromatographic isotope-ration mass spectroscopy. Individual AAs show isotopic discrimination with TL, while others are invariant. The magnitude of isotopic discrimination associated with those AAs that do show TL effects appear to be constant. McClelland \& Montoya (2002) determined that the difference in $\delta^{15} \mathrm{~N}$ between glutamate and phenylalanine in a consumer was $7 \%$ and could be used to estimate the relative trophic position of the consumer. Popp et al. (2007) used this approach by measuring $\delta^{15} \mathrm{~N}$ values of trophic (alanine, aspartic acid, and glutamic acid) and source (glycine, phenylalanine) AAs in yellowfin tuna Thunnus albacares to estimate tuna TL:

$$
\mathrm{TL}=1+\left(\delta^{15} \mathrm{~N}_{\text {Glutamic acid }}-\delta^{15} \mathrm{~N}_{\text {Glycine }}\right) / 7
$$

Should this relationship hold for marine food webs in general, this compound-specific approach will form a reliable means of determining trophic relationships and source of feeding in birds and will form the basis of a second generation of seabird trophic studies. However, recent investigations by Lorrain et al. (2009) on the isotopic composition of phenylalanine and glutamate in penguin blood suggest that the trophic enrichment factor between these AAs differs from $7 \%$, and more research is warranted.

While the laboratory analysis of individual compounds is involved and expensive, there are some 
key advantages over bulk tissues with the next generation of trophic modeling. Chief among these is that such compounds often have well defined metabolic pathways that are well understood and which involve no or well-constrained isotopic discrimination (Evershed et al. 2007). The nature of metabolic routing of key dietary components strongly suggests that the current difficulty of high variance related to isotopic discrimination and routing can be overcome by adopting an isotopic compound-specific approach to deciphering animal diets by using stable isotopes (Federer et al. 2010). For AAs, it is now clear that some differ little in their $\delta^{15} \mathrm{~N}$ values through food webs, whereas others change dramatically. This appears to be unrelated to whether such AAs are essential or non-essential, but instead likely corresponds to the ease with which they exchange $\mathrm{N}$ during trans-amination events (Wolf et al. 2009). By evaluating which AAs are variant and invariant in seabirds, the isotopic measurement of individual AAs in seabirds and their food webs promises to provide a much more reliable trophic model. Advantages of the isotopic analysis of individual FAs is less clear but likely will relate to the establishment of invariant signatures of source. Moreover, by using FA isotope analyses, a more quantitative estimate of contributions of sources of primary productivity over the use of FA analyses alone may be possible (e.g. Budge et al. 2008).

\section{Other isotopes}

We have emphasized here the use of $\delta^{15} \mathrm{~N}$ and $\delta^{13} \mathrm{C}$ measurements in seabird dietary studies, but it is worth considering the potential use of isotopes of other elements. $\delta^{34} \mathrm{~S}$ measurements have been used to characterize source of food in a variety of marine organisms. This isotope can be very useful in segregating pelagic versus inshore or benthic food webs and is very useful for delineating estuarine versus marine habitats (Peterson \& Fry 1987, Rubenstein \& Hobson 2004, Hebert et al. 2008, Moreno et al. 2010). Bird feathers are a particularly useful material for $\delta^{34} \mathrm{~S}$ analysis because they contain high concentrations of this element.

In terrestrial systems, $\delta^{2} \mathrm{H}$ and $\delta^{18} \mathrm{O}$ measurements are especially useful for assigning birds to origins (Hobson \& Wassenaar 2008). It has been assumed that these isotopes will be less useful in marine systems, where their values relative to the international standard, Vienna Standard Mean Ocean Water, are by definition 0 . However, isotopes of these elements are sensitive to temperature and freshwater influences in coastal regions and may prove to be useful components of marine isoscapes (see Schaffner \& Swart 1991, Ramos et al. 2009b, Hobson et al. 2010). Finally, there are a host of heavier elements that have been poorly investigated, but which show promise in future seabird applications, especially those related to source of feeding or transport of contaminants. These include the isotopes of $\mathrm{Pb}$ (Stewart \& Outridge 2003), Sr (Font et al. 2007, Hobson et al. 2010), and, more recently, Hg (Point et al. 2011). The improved availability of analytical instruments like inductively coupled plasma mass spectrometers will now accelerate research in these areas.

\section{Analytical methods and nomenclature}

Differences in analytical approaches may affect interpretation of isotopic data. Foremost among these is the issue of lipid extraction of tissues prior to analysis. Since lipids are more depleted in ${ }^{13} \mathrm{C}$ than other macromolecules, the differential presence of lipids in tissues can significantly affect tissue $\delta^{13} \mathrm{C}$ values. Because lipids are typically metabolically routed to either lipid stores or to energy production, the removal of lipids from analyses allows isotopic interpretations based largely on proteinaceous pathways for most marine consumers without the confounding factor of variable lipid contents. Some debate over whether or how to remove lipids has emerged, since some lipid extraction approaches can result in slight changes to tissue $\delta^{15} \mathrm{~N}$ values, due to the loss of some proteins. One solution is to split samples and run half for $\delta^{13} \mathrm{C}$ with lipid removal and the other half without lipid extraction for $\delta^{15} \mathrm{~N}$ measurements. Alternatively, one may use a post hoc correction for differential lipid content based on the elemental C:N ratio (e.g. Post et al. 2007, Logan et al. 2008, but see Oppel et al. 2010). Where seabird researchers are particularly interested in tissue $\delta^{13} \mathrm{C}$ values, a lipid-free $\delta^{13} \mathrm{C}$ value will be most useful. Importantly, seabird biologists should be careful when comparing isotope data among studies that have used different sample pretreatment protocols.

The measurement of $\delta^{13} \mathrm{C}, \delta^{15} \mathrm{~N}$, and $\delta^{34} \mathrm{~S}$ in organic materials is routine, with good agreement among most laboratories. However, the measurement of $\delta^{2} \mathrm{H}$ and $\delta^{18} \mathrm{O}$ is challenging, due to the fact that there are no internationally accepted standards for the measurement of non-exchangeable $\mathrm{H}$ in organic materials. Some laboratories have gone to great lengths to address this problem through the development of in- 
house standards (Qi et al. 2011), but others have not paid enough attention to this issue, and researchers must be careful when comparing data for these elements on organic materials.

The reporting of analytical error associated with isotopic measurements also varies among authors. Ideally, researchers will quote both the results of within-run replicate measurements of appropriate organic standards that span the range of their unknowns and are of similar material, as well as the long-term statistics of these standards over numerous runs (Jardine \& Cunjak 2005). Actual (\%) values of routine lab standards should be reported. Authors should refrain from reporting isotope measurements to more than 1 significant figure, since this is in keeping with actual measurement precision. Further recommendations on data reporting can be found in Bond \& Hobson (in press).

\section{Future directions}

The typical lack of taxonomic information on seabird diets that are better evaluated through the use of stomach content and FA analysis does not detract from the continued use of stable isotope methods in seabird ecological studies. Rather, the strengths of the isotope approach are complementary to these other approaches. Isotopic assays of tissues within the same individual provide information on diet that spans temporal ranges over days to months prior to sampling. No other technique provides this deep archival or retrospective capability and, of course, such methods can be applied to historic (Hobson \& Montevecchi 1991, Hobson et al. 2004, Becker \& Beissinger 2006, Emslie \& Patterson 2007, Norris et al. 2007), as well as contemporary seabird trophic investigations. Moreover, isotopic ratios integrate many behavioral and environmental events that ultimately describe the isotope space occupied by an individual and can be an appropriate means of examining competitive overlap and exclusion among individuals and populations (Bearhop et al. 2004, Newsome et al. 2007, Jaeger et al. 2009). The relative ease of sampling and laboratory analyses of the common stable isotopes of $\mathrm{C}, \mathrm{N}$, and $\mathrm{S}$, together with the low cost of analyses, are powerful incentives to use isotopic assays in seabird dietary and ecological investigations. The following are some recommendations to move this field forward:

(1) Refinement of our understanding of the variance associated with tissue-specific isotopic discrimination factors that link seabirds to their diet. Studies can be both field and laboratory based and can evaluate the effects of diet quality, growth stage, fasting, and environmental variables (Martínez del Rio et al. 2009, Bond \& Diamond 2011). Where considerable doubt remains about the validity of trophic models based on derived isotopic discrimination factors, researchers are encouraged to conduct sensitivity analyses using Bayesian-based mixing models.

(2) Trophic models based on isotopic differences between isotopically invariant and variant AAs need to be investigated further (Fig. 5). Continued research on the advantages of $\delta^{13} \mathrm{C}$ and $\delta^{2} \mathrm{H}$ analyses of individual FAs in seabirds and their eggs is also encouraged (Hobson 2011).

(3) Individual seabirds whose molt origins at sea have been established through independent means such as the use of satellite tags or geolocators must be sampled for isotopic assays. While spatial and temporal changes in diet need to be considered, the use of tissues from the tracked individuals will contribute to ground-truthing of marine isoscapes. Researchers should investigate isotopic measurements other than the more traditional $\delta^{13} \mathrm{C}, \delta^{15} \mathrm{~N}$, and $\delta^{34} \mathrm{~S}$ assays. However, for those isotopes whose

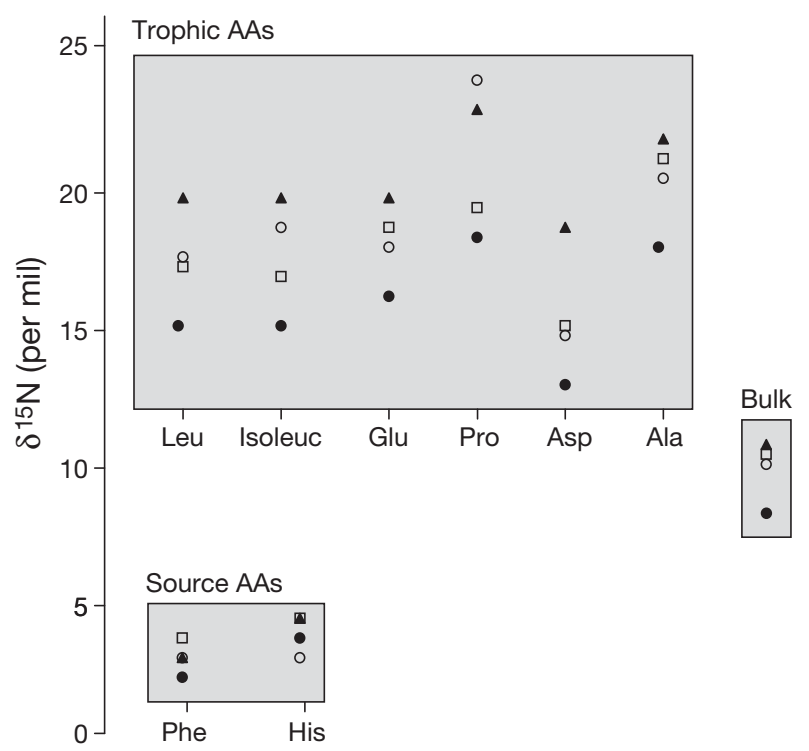

Fig. 5. Stable-nitrogen isotope values of individual amino acids (AAs) and bulk tissues of northern rockhopper penguin Eudyptes chrysocome moseleyi $(\mathrm{O})$, southern rockhopper penguin E. C. chrysocome (๑), king penguin Aptenodytes patagonicus ( $\square$ ), and Adélie penguins Pygoscelis adeliae $(\mathbf{\Delta})$. Source AAs are relatively invariant between trophic level (TL) and can be used to track variation in baseline isotope food web samples, whereas trophic AAs are enriched in ${ }^{15} \mathrm{~N}$ trophically. The difference between source and trophic AAs can be used to derive absolute trophic level in seabirds and other marine consumers (from Lorrain et al. 2009) 
behavior in foodwebs is less certain (e.g. regarding isotopic discrimination within food webs, metabolic routing, etc.), emphasis should be placed on controlled studies using captive animals to first establish basic principles.

\section{FATTY ACIDS}

\section{Background}

FAs comprise the majority of lipids found in all organisms. Their great diversity, conservation of structure during digestion, biochemical restrictions to synthesis and modification, and in some cases unique origins among plants and animals, have fostered research ranging from elucidating phylogenetic patterns in metabolism and biosynthesis to determining food web structure in complex marine ecosystems. Several reviews provide extensive background on the origins, structure, analysis, and use of FAs in tracing trophic relationships (Dalsgaard et al. 2003, Iverson et al. 2004, Budge et al. 2006, Iverson 2009, Tollit et al. 2010). We focus on the most recent advances and new directions, as well as challenges to further developing these techniques.

All FAs are composed of chains of carbon atoms with associated hydrogen atoms, most commonly in even-numbered straight chains of 14 to 24 carbons with 0 to 6 double bonds, with a terminal methyl $\left(-\mathrm{CH}_{3}\right)$ end and a terminal carboxyl $(-\mathrm{COOH})$ end. Double bonds are usually separated by a single methylene group $\left(\mathrm{CH}_{2}\right.$, i.e. methylene interrupted), and thus FAs are named by their carbon number: number of double bonds and location $(n-x)$ of the double bond nearest the terminal methyl group (the position of which is conserved), with all other double bond positions known to occur accordingly (e.g. 18:3n-3). In rare cases, FAs can also be non-methylene interrupted and are named instead with each double bond position indentified by $\Delta$ relative to the carboxyl end (e.g. 20:2 $\Delta 5,11$ ). The array of FAs in marine ecosystems is complex, with about 70 FAs routinely identified in any given organism or tissue (Iverson 2009). Several characteristics of FAs and their storage patterns make them very useful tracers of predator diets and marine foodweb structure (e.g. Cook 1996, Budge et al. 2006, Iverson 2009).

(1) Organisms are limited in their ability to biosynthesize, modify chain length, and introduce double bonds in FAs. Most biosynthesis of unique FAs occurs in primary producers and ectothermic consumers at the bottom of the food chain, whereas limitations in these processes are most pronounced with increasing phylogenetic order, culminating in endothermic, nonruminant vertebrates. Additionally, the propensity in endotherms, such as seabirds, for modifying FAs, even if the capacity exists, is greatly reduced when FAs are abundant, such as in prey inhabiting marine ecosystems.

(2) Unlike dietary proteins and carbohydrates, which are completely broken down during digestion, FAs are generally not degraded unless used immediately for energy. Instead, FAs are released from ingested lipid molecules (principally dietary triacylglycerols [TAG] but also wax esters [WE] from some prey), and are taken up into adipose tissue and reintegrated into TAG for storage in a conservative manner.

(3) Animals have a large capacity to store fat, which can be subsequently or alternately mobilized for short- or long-term energy demands. Thus, ingested FAs bioaccumulate in predator fat stores, principally adipose tissue. Thus, sampling predator fat storage reservoirs allows examination of the integration of FA ingestion over time.

In seabirds, the key lipid reservoirs and those most directly influenced by diet are adipose tissue and, in procellariiforms (e.g. albatrosses, shearwaters, fulmars, petrels), also stomach oils. Adipose tissue represents the integration of FAs from diet over time, after having undergone digestion and some metabolic processing. In contrast, stomach oils are produced from recent prey lipids ingested via a unique anatomical and physiological process (Roby et al. 1989), and have not been digested and have undergone minimal metabolic processing (Wang et al. 2007, Richoux et al. 2010). Although dietary FAs can also be isolated from blood, overall blood FA component is dominated by FAs produced endogenously, unless the bird has very recently (i.e. within hours) consumed a meal. In the latter case, the FAs from diet are carried for a short time in portomicrons (large triglyceride-rich lipoproteins) prior to uptake by tissues, which must be isolated from the other blood lipids to examine dietary FA intake from the last meal only (e.g. see Cooper et al. 2005).

\section{Qualitative approaches to investigation of foraging patterns}

FAs can be used to study trophic relationships and food webs of seabirds in several ways, with interpretations depending on the tissue sampled. The most common approaches - and with the longest history by far-are using FAs qualitatively or semi-quantita- 
tively to examine empirically determined differences among predators in levels of specific FAs or in complete arrays of FAs (FA signatures; Iverson 1993), which indicate differences in diet(s) among individuals, populations, and species. Additionally, if something is known about unique or unusual FA characteristics or ratios of specific FAs in certain prey, it may then be possible to attribute the predator differences to consumption of specific prey, especially if there is other evidence available from traditional diet analyses (e.g. stomach contents) or from stable isotope information. Specific FAs have been referred to as 'biomarkers' for distinguishing certain food sources, e.g. by differentiating primary producers and bacteria, indicating certain primary consumers such as copepods, identifying markers of carnivory, or distinguishing terrestrial versus marine sources (e.g. Fig. 6; reviewed by Dalsgaard et al. 2003, Budge et al. 2006, Iverson 2009).

While unusual levels of certain FAs or ratios among FAs can sometimes be attributed to only 1 or a few prey types and thus indicate their importance in the diet of a consumer, this possibility is rare in higher TL predators such as seabirds. FAs originating at the base of the food web become ubiquitous throughout higher levels, and as TLs increase, the ability to use a single FA or ratio of FAs to trace feeding to a specific food type is greatly reduced. Thus, in higher predators such as seabirds, there are few 'biomarker' FAs, which by definition should be unique to only a single or several prey items and traceable directly to con-

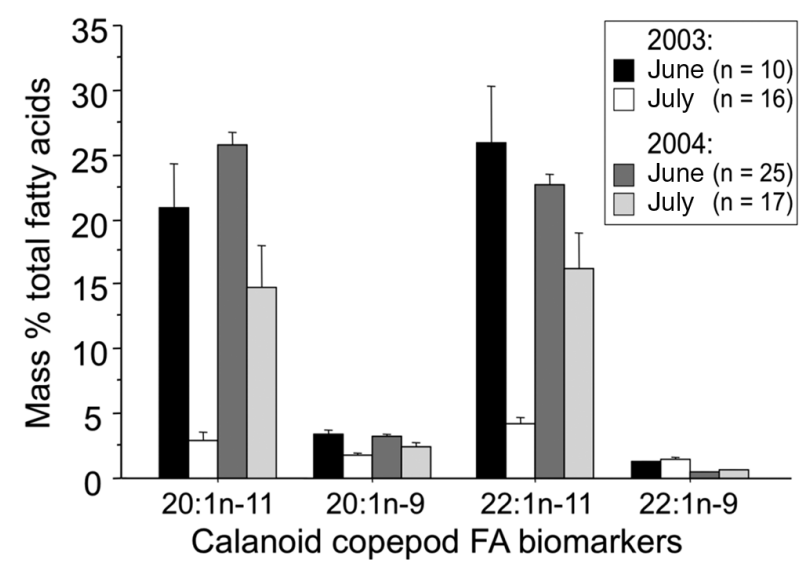

Fig. 6. Aethia pusilla. Copepod fatty acid (FA) biomarkers (mean \pm SE) in adipose tissue from adult least auklets in the 2003 and 2004 breeding seasons on St. Paul Island, Alaska (USA). The high levels of these biomarkers in early June of both years indicate that copepods had been abundantly available for several weeks. By July in both years, the decline in these FAs was consistent with the relative timing of the decline of copepods documented in each year, and illustrates the sensitivity of FA signatures to changes in diet, which indicate environmental changes. Data from Springer et al. (2007) suming that prey. Although it may be easier to trace diet items using marker FAs or ratios in seabirds that feed on primary consumers (e.g. least auklets, Fig. 6) than in piscivores, there may still be the problem of most prey items sharing a similar suite of FAs (albeit at differing levels, depending on the prey type and species). However, in the unique case of procellariiforms, another compound at the whole lipid level can be used as a type of biomarker. Only certain prey species synthesize and store FAs in WE rather than as TAG, and in some ecosystems, WE may be confined to only 1 or a few prey species (e.g. copepods, myctophids). Since procellariiform stomach oils have not undergone digestion, the presence of WE can be used as confirmation of consumption of those prey species that make $\mathrm{WE}$, and also provides the opportunity to examine different time scales of dietary integration by comparing with FAs in adipose tissue TAG, which represent consumption over a longer time frame (Wang et al. 2007, Iverson 2009).

Despite the various limitations discussed above, evaluating variation in FAs and FA signatures among individuals and populations of seabirds remains a promising, qualitative, way to investigate trophic interactions and to detect dietary differences. Differences in FA patterns among individuals and populations translate directly to differences in dietary intake, even if that dietary intake is not fully elucidated. For instance, FAs have been used in such qualitative or semi-quantitative ways to investigate spatial and temporal differences in foraging patterns as well as to confirm general resource use of a number of seabird species (e.g. Dahl et al. 2003, Connan et al. 2005, Iverson et al. 2007, Käkelä et al. 2007, 2010, Springer et al. 2007, Karnovsky et al. 2008, Williams et al. 2008, Wang et al. 2009, Ronconi et al. 2010). When such FA patterns are used in combination with other diet information (e.g. direct observation, stomach contents, stable isotopes), results are compelling (e.g. Connan et al. 2007, Iverson et al. 2007, Springer et al. 2007, Karnovsky et al. 2008, Ronconi et al. 2010). This qualitative use of FAs provides valuable information that is likely not possible to obtain otherwise, but, it will generally not allow specific interpretation of seabird diet composition.

\section{Quantitative estimation of diets}

The existence of clearly distinguished patterns of FAs (FA signatures) among different prey species or types in a given ecosystem (e.g. Budge et al. 2002, Iverson et al. 2002, Piche et al. 2010), combined with 
the understanding that FAs are predictably deposited in predator adipose tissue, raises the possibility of quantifying diets by determining the most likely mixture of prey signatures that could account for the predator's FA signature. This is the area of greatest current interest and innovation (Iverson 2009). Quantitative FA signature analysis (QFASA; Iverson et al. 2004) is a first-generation statistical tool developed to determine the weighted mixture of prey species FA signatures that most closely resembles that of the predator's FA stores, thereby inferring its diet. With comparable underpinnings, QFASA is in principle similar to mixture models developed for stable isotopes (e.g. Phillips \& Koch 2002, Phillips \& Gregg 2003). Assuming appropriate sampling of predator and prey lipids (reviewed by Budge et al. 2006, Iverson 2009), QFASA proceeds by applying experimentally derived weighting factors (calibration coefficients, CCs) to individual predator FAs to account for the effects of predator metabolism on FA deposition. It then takes the average FA signature of each prey species (or group), and estimates the mixture of prey signatures that comes closest to matching that of the weighted predator's FA stores by minimizing the statistical distance between that prey species mixture and the weighted predator FA profile. Lastly, this proportional FA mixture is weighted by the fat content (i.e. relative FA contribution) of each prey species to estimate the proportions of each prey in the predator's diet (Iverson et al. 2004).

The use of CCs to account for imperfect mixing of all ingested prey FAs into adipose tissue due to metabolism effects in the predator overcomes some of the problematic assumptions of complete dietary mixing as in the early isotopic mixing models (see 'Stable isotopes: mixing models'). CCs are determined from captive validation studies in which a predator consumes a single diet over a period long enough for complete FA turnover, assuming then that the FA signature of the predator's lipid stores will resemble the diet FA signature as much as possible and any differences can be attributed to metabolic processing of individual FAs. To date, seabird adipose tissue CCs have been estimated in chicks of common murres and tufted puffins Fratercula cirrhata and in adults of Steller's eiders Polysticta stelleri, spectacled eiders Somateria fischeri and yellowlegged gulls Larus michahellis (Iverson et al. 2007, Williams et al. 2009, Wang et al. 2010, Käkelä et al. 2010). Although the CCs estimated from the various studies share many similarities (including some similarities with CCs determined for marine mammals; Iverson 2009), it is not yet known whether differences are due to species, age (adult versus chick), feeding regime, and/or study effects. Additionally, while CCs are critical to the accurate performance of QFASA, they remain a relatively simple mathematical attempt to describe potentially complex biochemistry. Thus, further captive validations will be extremely useful in advancing this aspect of QFASA. Additionally, Wang et al. (2007) proposed the possibility of using stomach oil FAs in procellariiforms to estimate adipose tissue $\mathrm{CCs}$ in the same individuals if on long-term constant diets (i.e. using stomach oil as proxy for prey), since little to no metabolic processing appears to have occurred. Alternatively, Wang et al. (2007) suggested the potential for using stomach oil FAs directly without CCs to estimate recent diet using QFASA.

Besides CCs, perhaps the next most important issue to using QFASA is building an appropriate and comprehensive prey database and sampling all species sufficiently to allow quantitative evaluation of within- and between-species variability to confirm the ability to reliably differentiate prey species in the QFASA model (e.g. Iverson et al. 2004, Budge et al. 2006, Iverson 2009). Depending on the ecosystem and logistics, this can be a daunting task. Additionally, depending on the complexity of the array of prey species and shared ecology, it is unlikely that all individual species in an ecosystem can be differentiated from one another based on their FA signatures. Thus, the onus is on the researcher to make decisions based upon empirical evidence, testing, and evaluation of potential confounding of prey species and which species to include, exclude, or group based on ecological equivalence and taxonomy (e.g. Piche et al. 2010). This is also where the use of multiple tools in diet analyses can be extremely informative (see also 'Future directions' below).

The other issues that remain important for interpretation of seabird diets using FA signatures include which FA subset should be used in the QFASA model. Not all FAs provide information on diet, and certainly FAs that provide no link to diet should be removed (see Iverson et al. 2004). Beyond that, the FA subset to use will also depend on accuracy of measurements and confidence in trace FA measurement, as well as reliability with which CCs for specific FAs are measured. Secondly, a better understanding is needed of the time frames of FA turnover in fat stores and thus the time frame of dietary history they represent. Several controlled studies have been conducted that begin to address this in seabirds (Williams et al. 2009, Wang et al. 2010). However, how these time fames differ during periods of fat storage versus high-energy use is not known. The pre- 
cise time frame of food consumption that stomach oils represent is also unclear. Despite these issues, QFASA estimates of diet have now been validated in captive common murre and red-legged kittiwake Rissa brevirostris chicks and adult Steller's and spectacled eiders in diet trials involving relatively simple diet mixtures (3 to 5 prey species; Iverson et al. 2007, Wang et al. 2010). Although, in principle, diet estimates using QFASA versus stomach content analyses would not be expected to be identical, given the different time frames they represent and other methodassociated biases, the comparison of both can prove informative and has served as validation of QFASA in free-ranging adult common murres, thick-billed murres, red-legged kittiwakes, and black-legged kittiwakes involving a complex ecosystem-wide mixture of prey species (Fig. 7; Iverson et al. 2007).

\section{Future directions}

The original QFASA model of Iverson et al. (2004) is a first-generation mixing model, which explicitly incorporates information on predator metabolism and prey fat content into the statistical estimation procedure. As stated above, the current model has several absolute requirements, which need to be further evaluated and verified. In addition to these issues are those of the evolution, refinement, and improvement of the QFASA model. The following include recommendations in advancing the use of FAs to understand seabird diets.

Further evaluation of QFASA model components

(1) Prey FA catalogues or 'libraries' are required for the modeling of any predator diet, but these cannot just be collections of prey that are blindly included in model estimations. Prey FA signatures not only differ across species, but can also vary within species over spatial and temporal scales or within demographic groups such as in juveniles and adults that have different feeding patterns (e.g. Iverson et al. 2002). This variation must be investigated to determine the actual effect on diet estimates using QFASA and hence the creation of appropriate within or among prey species separations or groupings. Additionally, given the onerous task of building any prey database for a given predator, collaboration among researchers

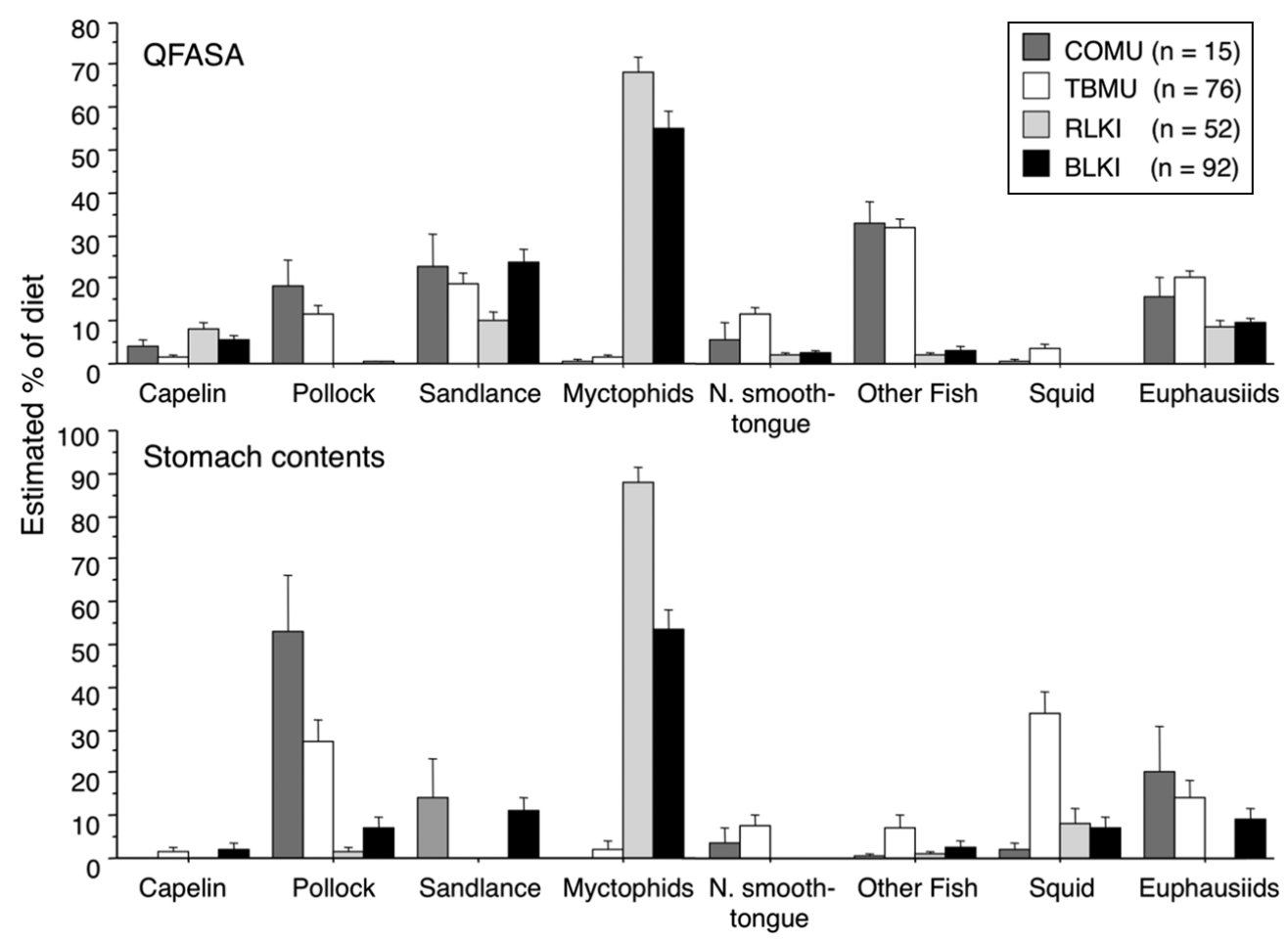

Fig. 7. Diet estimates of free-ranging common and thick-billed murres (COMU, TBMU) and red-and black-legged kittiwakes (RLKI, BLKI) $(\mathrm{n}=235)$ in the Bering Sea using quantitative fatty acid signature analysis (QFASA) modeled on 161 prey representing 15 species, in comparison with stomach content analysis in the same individuals (mean \pm SE). Only prey species appearing in diet estimates are presented. Reproduced from data in Iverson et al. (2007) 
to develop a global reference database of prey FA signatures across different studies that span different ecoregions and time scales would greatly aid the advancement and use of QFASA.

(2) Further captive validation studies to determine CCs across species continue to be of paramount importance. The outputs of the QFASA model are extremely sensitive to the CCs used and a better understanding or refinement of the effects on CCs of species, age (i.e. adults versus growing chicks), and diet (e.g. high versus low fat; prey with widely different FA signatures) would improve the application of QFASA to estimating diets. Such studies will also be important for improving determination of the time frame that estimated diets represent in seabirds.

(3) Finally, through the above-mentioned further captive validation studies, a refinement in determination of the most appropriate FA subsets to use in QFASA will improve the accuracy of diet estimates.

\section{Advanced FA mixing models}

The current QFASA model provides point estimates of diet, using average prey FA signatures, with the large amount of variability in prey FA profiles captured using a bootstrapping procedure to compute standard errors for diet composition vectors (Iverson et al. 2004). In subsequent work, Stewart (2005) developed a means to produce interval estimates of diet, exploring alternative ways to summarize prey by random sampling and re-sampling, and also exploring a means of estimating goodness of fit with compositional data. However, in both methods, no other prior information was incorporated in the mixing models. Most recently, effort has been focused on developing a Bayesian approach to the mixing model, which allows for incorporation of prior information on diet composition and prey FAs when available and, perhaps more importantly, gives an accurate account of uncertainty (Blanchard 2011). Additionally, it allows diet estimations to be made at both the population level as well as with the individual predator. The Bayesian method provides more accurate diet estimations when using synthetic data sets. However, in real predators, the multicollinearity of prey FAs - that is, where prey species have similar FA compositions-remains an issue (Blanchard 2011). Strategies for dealing with this issue are discussed, but clearly, explicitly incorporating more prior information from other sources should improve the accuracy of diet estimates.

\section{FA-stable isotope-specific analyses}

As discussed previously, like FAs, stable isotope signatures are transferred in largely predictable ways from the diet to the predator. But isotopically distinct dietary sources do not always exist and there can also be multicollinearity in prey FAs among species. To deal with such issues in both methods, the possibility of coupling the analysis of FAs and stable isotopes should be a new frontier in elucidating diet. That is, by analyzing the stable isotopes of individual FAs, we may better be able to trace FA patterns to prey at various TLs and perhaps incorporate such information into various mixing models. This was demonstrated in a preliminary study by Budge et al. (2008), which allowed the use of mass balance calculations to estimate the contributions of ice algae versus water-column phytoplankton to sequentially higher TLs, culminating in seabirds and marine mammals. This accomplishment could not have been possible using FA signatures alone. Given the success of this attempt to trace carbon sources from the very bottom to the very top of a food web, it should be possible to use such a combination of techniques to answer more simple questions in differentiating direct prey species of seabird predators.

\section{CONCLUSIONS}

While each of the 3 techniques for determining seabird diets and ecological position can be used on its own, when they are applied in combination, oftentimes the limitations inherent in each of the techniques can be overcome. For example, traditional stomach content analysis can be used to validate shifts in diets determined from stable isotope or FA analysis. Likewise, stable isotope and FA analysis can be used to confirm dietary patterns suggested by stomach content findings. Karnovsky et al. (2008) found that little auks shift their TL up in the fall; their FAs then resembled the signatures of black-legged kittiwakes, and their stomach contents included prey that were found only in those species at that time of year. In a similar fashion, Connan et al. (2010) combined all 3 techniques to reveal that provisioning Tasmanian short-tailed shearwaters Puffinus tenuirostris feed in Antarctic waters (stable isotope analysis) on myctophids (FA) when self-feeding, which is in contrast to the euphausiid-dominated diets they collected for chicks.

A significant challenge in combining several analytical techniques to examine seabird diet and 
the source of feeding clearly is the statistical integration of disparate information. Currently, Bayesian and likelihood methods of examining this question seem best suited to the use of probabilistic models. Such approaches will allow the use of informative priors to guide model estimates. For example, stomach content data can be used to inform stable isotope and FA model estimates (Moore \& Semmens 2008). Likewise, Polito et al. (2011) found that Bayesian isotope mixing models could not estimate the fish component of penguin diets accurately without incorporating the results of stomach content analysis. They used the estimates of the relative contribution of specific fish species with similar TLs to refine their 2-source isotopic mixing model. Application of stomach content analysis alone underestimated the biomass contribution of fish to the penguin diets, which were better assessed using stable isotope analysis. Their study showed how integrating the 2 methods greatly enhanced their ability to quantify penguin diets through the use of Bayesian mixing models (Polito et al. 2011).

In addition to enhancing understanding of shifts in oceanographic conditions through the study of seabird diets, these data are critical for the development of conservation strategies for seabirds. For example, Ramos et al. (2011) were able to predict how management strategies would impact different colonies of yellow-legged gull Larus michahellis, through an inter-colony comparison of stable isotopes in feathers. Critically endangered Balearic shearwaters Puffinus mauretanicus showed geographic variation in stable isotopes of feathers, which gave support for particular foraging areas to become Marine Protected Areas (Louzao et al. 2011). Maranto et al. (2011) used FA biomarkers to identify the colony origins of terns killed at inland dams as part of a lethal control program meant to protect juvenile salmonids. Their results showed that the birds feeding at the dams were not of local origin so extirpation of the colony closest to the dam would not be effective in protecting salmonids (Maranto et al. 2011).

We are confident that the next decade will see the formal development of such multiple-technique approaches to seabird dietary studies within a strong analytical framework. More and more, we are also witnessing the use of multiple tools together to answer fundamental questions related to diet and source of feeding. Rather than relying on a single tool, such studies provide a 'weight of evidence' approach to dietary investigations.
Acknowledgements. We thank G.L. Hunt, Jr. and R.P. Wilson, conveners of the session 'Technological and Analytical Innovation in Seabird Research,' for inviting the presentation of this material at the 1st World Seabird Conference, Victoria, Canada, 7-11 September 2010. Figs. 1 \& 2 are from work supported by National Science Foundation Office of Polar Programs grant OPP 9725071 to G.L. Hunt, Jr.

\section{LITERATURE CITED}

Abraham CL, Sydeman WJ (2006) Prey-switching by Cassin's auklet Ptychoramphus aleuticus reveals seasonal climate-related cycles of Euphausia pacifica and Thysanoessa spinifera. Mar Ecol Prog Ser 313:271-283

Ainley DG, Ballard G, Barton KJ, Karl BJ, Rau GH, Ribic CA, Wilson PR (2003) Spatial and temporal variation of diet within a presumed metapopulation of Adélie penguins. Condor 105:95-106

Awkerman JA, Hobson KA, Anderson DJ (2007) Isotopic $\left(\delta^{15} \mathrm{~N}\right.$ and $\left.\delta^{13} \mathrm{C}\right)$ evidence for intersexual foraging differences and temporal variation in habitat use in waved albatrosses. Can J Zool 85:273-279

Barnes C, Jennings S, Barry JT (2009) Environmental correlates of large-scale spatial variation in the $\delta^{13} \mathrm{C}$ of marine animals. Estuar Coast Shelf Sci 81:368-374

Barnes C, Irigoien X, De Oliveiria JAA, Maxwell D, Jennings S (2011) Predicting marine phytoplankton community size structure from empirical relationships with remotely sensed variables. J Plankton Res 33:13-24

Barrett RT, Camphuysen KCJ, Anker-Nilssen T, Chardine JW and others (2007) Diet studies of seabirds: a review and recommendations. ICES J Mar Sci 64:1675-1691

Bearhop S, Phillips RA, Thompson DR, Waldron S, Furness RW (2000) Variability in mercury concentrations of great skuas Catharacta skua: the influence of colony, diet and trophic status inferred from stable isotope signatures. Mar Ecol Prog Ser 195:261-268

Bearhop S, Waldron S, Votier SC, Furness RW (2002) Factors that influence assimilation rates and fractionation of nitrogen and carbon stable isotope signatures in avian blood and feathers. Physiol Biochem Zool 75:451-458

> Bearhop S, Adams CE, Waldron S, Fuller RA, Macleod H (2004) Determining trophic niche width: a novel approach using stable isotope analysis. J Anim Ecol 73: 1007-1012

Becker BH, Beissinger SR (2006) Centennial decline in the trophic level of an endangered seabird after fisheries decline. Conserv Biol 20:470-479

Blanchard WJ (2011) Inference on the diet composition of predators using fatty acid signatures: an application of Bayesian inference on linear mixing models. PhD thesis, Dalhousie University, Halifax, NS

Bond AL, Diamond AW (2011) Recent Bayesian stableisotope mixing models are highly sensitive to variation in discrimination factors. Ecol Appl 21:1017-1023

Bond AL, Hobson KA (2012) Reporting stable-isotope ratios in ecology: recommended terminology, guidelines, and best practices. Waterbirds (in press)

Bond AL, Jones IL (2009) A practical introduction to stableisotope analysis for seabird biologists: approaches, cautions and caveats. Mar Ornithol 37:183-188

> Budge SM, Iverson SJ, Bowen WD, Ackman RG (2002) Among- and within-species variation in fatty acid signatures of marine fish and invertebrates on the Scotian 
Shelf, Georges Bank and southern Gulf of St. Lawrence. Can J Fish Aquat Sci 59:886-898

Budge SM, Iverson SJ, Koopman HN (2006) Studying trophic ecology in marine ecosystems using fatty acids: a primer on analysis and interpretation. Mar Mamm Sci 22: 759-801

Budge SM, Wooller MJ, Springer AM, Iverson SJ, McRoy CP, Divoky GJ (2008) Tracing carbon flow in an arctic marine food web using fatty acid stable isotope analysis. Oecologia 157:117-129

Carleton SA, Martínez del Rio C (2005) The effect of coldinduced increased metabolic rate on the rate of ${ }^{13} \mathrm{C}$ and ${ }^{15} \mathrm{~N}$ incorporation in house sparrows (Passer domesticus). Oecologia 144:226-232

$>$ Caut S, Angulo E, Courchamp F (2008a) Caution on isotope model use for analyses of consumer diet. Can J Zool 86: 438-445

$>$ Caut S, Angulo E, Courchamp F (2008b) Discrimination factors $\left(\delta^{15} \mathrm{~N}\right.$ and $\left.\delta^{13} \mathrm{C}\right)$ in an omnivorous consumer: effect of diet isotopic ratio. Funct Ecol 22:255-263

Caut S, Angulo E, Courchamp F (2008c) Dietary shift of an invasive predator: rats, seabirds and sea turtles. J Appl Ecol 45:428-437

Cerling TE, Ayliff LK, Dearing MD, Ehleringer JR and others (2007) Determining biological tissue turnover using stable isotopes: the reaction progress variable. Oecologia 151:175-189

- Cherel Y, Hobson KA (2007) Geographical variation in carbon stable isotope signatures of marine predators: a tool to investigate their foraging areas in the Southern Ocean. Mar Ecol Prog Ser 329:281-287

> Cherel Y, Bocher P, Trouve C, Weimerskirch H (2002) Diet and feeding ecology of blue petrels Halobaena caerulea at Iles Kerguelen, Southern Indian Ocean. Mar Ecol Prog Ser 228:283-299

> Cherel Y, Hobson KA, Weimerskirch H (2005) Using stable isotopes to study resource acquisition and allocation in procellariiform seabirds. Oecologia 145:533-540

Cherel Y, Le Corre M, Jaquemet S, Menard F, Richard F, Weimerskirch H (2008) Resource partitioning within a tropical seabird community: new information from stable isotopes. Mar Ecol Prog Ser 366:281-291

> Cherry SG, Derocher AE, Hobson KA, Stirling I, Thiemann GW (2011) Quantifying dietary pathways of proteins and lipids to tissues of a marine predator. J Appl Ecol 48: 373-381

- Connan M, Mayzaud P, Boutoute M, Weimerskirch $H_{\text {, }}$ Cherel Y (2005) Lipid composition of stomach oil in a procellariiform seabird Puffinus tenuirostris: implications for food web studies. Mar Ecol Prog Ser 290:277-290

> Connan M, Cherel Y, Mabille G, Mayzaud P (2007) Trophic relationships of white-chinned petrels from Crozet Islands: combined stomach oil and conventional dietary analyses. Mar Biol 152:95-107

Connan M, Mayzaud P, Hobson KA, Weimerskirch $\mathrm{H}$, Cherel Y (2010) Food and feeding ecology of the Tasmanian short-tailed shearwater (Puffinus tenuirostris, Temminck): insights from three complementary methods. J Oceanogr Res Data 3:19-32

Cook HW (1996) Fatty acid desaturation and chain elongation in eukaryotes. In: Vance DE, Vance JE (eds) Biochemistry of lipids and membranes. Elsevier, Amsterdam, p 129-152

Cooper MH, Iverson SJ, Heras H (2005) Dynamics of blood chylomicron fatty acids in a marine carnivore: implica- tions for lipid metabolism and quantitative estimation of predator diets. J Comp Physiol B Biochem Syst Environ Physiol 175:133-145

Cury PM, Boyd IL, Bonhommeau S, Anker-Nilssen T and others (2011) Global seabird response to forage fish depletion-one-third for the birds. Science 334: 1703-1706

Dahl TM, Falk-Petersen S, Gabrielsen GW, Sargent JR, Hop H, Millar RM (2003) Lipids and stable isotopes in common eider, black-legged kittiwake and northern fulmar: a trophic study from an Arctic fjord. Mar Ecol Prog Ser 256:257-269

> Dalsgaard J, St John M, Kattner G, Muller-Navarra DC, Hagen W (2003) Fatty acid trophic markers in the pelagic marine environment. Adv Mar Biol 46:225-340

Deagle BE, Gales NJ, Evans K, Jarman SN, Robinson S, Trebilco R, Hindell MA (2007) Studying seabird diet through genetic analysis of faeces: a case study on macaroni penguins (Eudyptes chrysolophus). PLoS ONE 2:e831 doi: 10.1371/journal.pone.0000831

Deagle BE, Chiaradia A, McInnes J, Jarman SN (2010) Pyrosequencing faecal DNA to determine diet of little penguins: is what goes in what comes out? Conserv Genet 11:2039-2048

> Duffy DC, Jackson S (1986) Diet studies of seabirds: a review of methods. Colon Waterbirds 9:1-17

> Duffy DC, Laurenson LB (1983) Pellets of cape cormorants as indicators of diet. Condor 85:305-307

Emslie SD, Patterson WP (2007) Abrupt recent shift in $\delta^{13} \mathrm{C}$ and $\delta^{15} \mathrm{~N}$ values in Adelie penguin eggshell in Antarctica. Proc Natl Acad Sci USA 104:11666-11669

Evans Ogden LJ, Hobson KA, Lank DB (2004) Blood isotopic $\left(\delta^{13} \mathrm{C}\right.$ and $\left.\delta^{15} \mathrm{~N}\right)$ turnover and diet-tissue fractionation factors in captive dunlin. Auk 121:170-177

Evershed RP, Bull ID, Corr LT, Crossman ZM and others (2007) Compound-specific stable isotope analysis in ecology and paleoecology. In: Michener R, Lajtha K (eds) Stable isotopes in ecology and environmental science. Blackwell, London, p 480-540

> Federer RN, Hollmen TE, Esler D, Wooller MJ, Wang SW (2010) stable carbon and nitrogen isotope discrimination factors from diet to blood plasma, cellular blood, feathers, and adipose tissue fatty acids in spectacled eiders (Somateria fischeri). Can J Zool 88:866-874

$>$ Font L, Nowell GM, Pearson DG, Ottley CJ, Willis SG (2007) Sr analysis of bird feathers by TIMS: a tool to trace bird migration paths and breeding sites. J Anal At Spectrom 22:513-522

Forero MG, Hobson KA (2003) Using isotopes of nitrogen and carbon to study seabird ecology: applications in the Mediterranean seabird community. Sci Mar 67:23-32

Forero MG, Hobson KA, Botolotti GR, Donazar JA, Bertelloti M, Blanco G (2002) Food resource utilisation by the Magellanic penguin revealed through stable-isotope analysis: segregation by sex and age and influence on offspring quality. Mar Ecol Prog Ser 234:289-299

Forero MG, Bortolotti GR, Hobson KA, Donazar JA, Bertolotti M, Blanco G (2004) High trophic overlap within the seabird community of Argentinean Patagonia: a multiscale approach. J Anim Ecol 73:789-801

> Forero MG, Gonzalez-Solis J, Hobson KA, Dnazar JA, Bertelloti M, Blamco G, Bortolotti GR (2005) Stable isotopes reveal trophic segregation by sex and age in the southern giant petrel in two different food webs. Mar Ecol Prog Ser 296:107-113 
Furness BL, Laugksch RC, Duffy DC (1984) Cephalopod beaks and studies of seabird diets. Auk 101:619-620

Gales RP (1988) The use of otoliths as indicators of little penguin Eudytula minor diet. Ibis 130:418-426

Gaston, AJ, Woo K, Hipfner M (2003) Trends in forage fish populations in northern Hudson Bay since 1981, as determined from the diet of nestling thick-billed murres, Uria lomvia. Arctic 56:227-233

Gómez-Díaz E, González-Solís J (2007) Geographic assignment of seabirds to their origin; combining morphologic, genetic, and biogeochemical analyses. Ecol Appl 17: $1484-1498$

Gon O, Heemstra PC (1990) Fishes of the Southern Ocean. JLB Smith, Institute of Ichthyology, Grahamstown

> González-Solís J, Smyrli M, Militão T, Gremillet D, Tveraa T, Phillips RA, Boulinier T (2011) Combining stable isotope analyses and geolocation to reveal kittiwake migration. Mar Ecol Prog Ser 435:251-261

Graham BS, Koch PL, Newsome SS, McMahon KW, Aurioles D (2010) Using isoscapes to trace the movements and foraging behavior of top predators in oceanic ecosystems. In: West JB, Bowen GJ, Dawson TE, Tu KP (eds) Isoscapes: understanding movement, pattern and process on earth through isotope mapping. Springer, London, p 299-318

Hansel HC, Duke SD, Lofy PT, Gray GA (1988) Use of diagnostic bones to identify and estimate original lengths of ingested prey fishes. Trans Am Fish Soc 117:55-62

Harris MP, Wanless S (1992) The importance of the lesser sandeel Ammodytes marinus in the diet of the shag Phalacrocorax aristotelis. Ornis Scand 23:375-382

> Hebert CE, Bur M, Sherman D, Shutt JL (2008) Sulfur isotopes link overwinter habitat use and breeding condition in double-crested cormorants. Ecol Appl 18:561-567

Hecht T (1987) A guide to the otoliths of Southern Ocean fishes. S Afr J Antarct Res 17:1-87

- Hedd A, Montevecchi WA (2006) Diet and trophic position of Leach's storm-petrel Oceanodroma leucorhoa during breeding and moult, inferred from stable isotope analysis of feathers. Mar Ecol Prog Ser 322:291-301

Hedd A, Fifield DA, Burke CM, Montevecchi WA and others (2010) Seasonal shift in the foraging niche of Atlantic puffins Fratercula arctica revealed by stable isotope $\left(\delta^{15} \mathrm{~N}\right.$ and $\left.\delta^{13} \mathrm{C}\right)$ analyses. Aquat Biol 9:13-22

- Hipfner JM, Hobson KA, Dale J, McGraw KJ (2010) Stable isotopes link diet to avian yolk carotenoid allocation: a comparative study of five auk species (Charadriiformes: Alcidae). Physiol Biochem Zool 83:481-489

Hobson KA (1987) Use of stable-carbon isotope analysis to estimate marine and terrestrial protein content in gull diets. Can J Zool 65:1210-1213

Hobson KA (1993) Trophic relationships among high Arctic seabirds: insights from tissue-dependent stable-isotope models. Mar Ecol Prog Ser 95:7-18

Hobson KA (2011) Isotopic ornithology: a perspective. J Ornithol 152:49-66

Hobson KA, Clark RW (1992) Assessing avian diets using stable isotopes. I: Turnover of ${ }^{13} \mathrm{C}$ in tissues. Condor 94 : 181-188

Hobson KA, Montevecchi WA (1991) Stable isotopic determinations of trophic relationships of great auks. Oecologia 87:528-531

Hobson KA, Wassenaar LI (eds) (2008) Tracking animal migration using stable isotopes. Handbook of terrestrial ecology series. Academic Press/Elsevier, Amsterdam
Hobson KA, Welch HE (1992) Determination of trophic relationships within a high Arctic marine food web using $\delta^{13} \mathrm{C}$ and $\delta^{15} \mathrm{~N}$ analysis. Mar Ecol Prog Ser 84:9-18

> Hobson KA, Alisasukas RT, Clark RG (1993) Stable nitrogen isotope enrichment in avian tissues due to fasting and nutritional stress: implications for isotopic analyses of diet. Condor 95:388-394

> Hobson KA, Piatt JF, Pitocchelli J (1994) Using stable isotopes to determine seabird trophic relationships. J Anim Ecol 63:786-798

Hobson KA, Gilchrist G, Falk K (2002a) Isotopic investigations of seabirds of the North Water Polynya: contrasting trophic relationships between the eastern and western sectors. Condor 104:1-11

Hobson KA, Fisk AT, Karnovsky N, Holst M, Gagnon JM, Fortier M (2002b) A stable isotope $\left({ }^{13} \mathrm{C},{ }^{15} \mathrm{~N}\right)$ model for the North Water Polynya foodweb: implications for evaluating trophodynamics and the flow of energy and contaminants. Deep-Sea Res II 49:5131-5150

> Hobson KA, Sinclair EH, York AE, Thomason J, Merrick RE (2004) Retrospective isotopic analyses of Steller's sea lion tooth annuli and seabird feathers: a cross-taxa approach to investigating regime and dietary shifts in the Gulf of Alaska. Mar Mamm Sci 20:621-638

Hobson KA, Barnett-Johnson R, Cerling T (2010) Using isoscapes to track animal migration. In: West J, Bowen GJ, Tu K, Dawson T (eds) Isoscapes: isotope mapping and its applications. Springer-Verlag, New York, NY, p 273-298

Hodum PJ, Hobson KA (2000) Trophic relationships among Antarctic fulmarine petrels: insights into dietary overlap and chick provisioning strategies inferred from stableisotope $\left(\delta^{15} \mathrm{~N}\right.$ and $\left.\delta^{13} \mathrm{C}\right)$ analyses. Mar Ecol Prog Ser 198: 273-281

Hunt GL Jr (1972) Influence of food distribution and human disturbance on the reproductive success of herring gulls. Ecology 53:1051-1061

> Inger R, Bearhop S (2008) Applications of stable isotope analyses to avian ecology. Ibis 150:447-461

Iverson SJ (1993) Milk secretion in marine mammals in relation to foraging: can milk fatty acids predict diet? Symp Zool Soc Lond 66:263-291

Iverson SJ (2009) Tracing aquatic food webs using fatty acids: from qualitative indicators to quantitative determination. In: Arts MT, Brett MT, Kainz M (eds) Lipids in aquatic ecosystems. Springer-Verlag, New York, NY, p 281-307

> Iverson SJ, Frost KJ, Lang SLC (2002) Fat content and fatty acid composition of forage fish and invertebrates in Prince William Sound, Alaska: factors contributing to among and within species variability. Mar Ecol Prog Ser 241:161-181

Iverson SJ, Field C, Bowen WD, Blanchard W (2004) Quantitative fatty acid signature analysis: a new method of estimating predator diets. Ecol Monogr 74:211-235

Iverson SJ, Springer AM, Kitaysky AS (2007) Seabirds as indicators of food web structure and ecosystem variability: qualitative and quantitative diet analyses using fatty acids. Mar Ecol Prog Ser 352:235-244

Jablonski B (1985) The diet of penguins on King George Island, South Shetland Islands. Acta Zool Cracov 29: $117-186$

Jaeger A, Cherel Y (2011) Isotopic investigation of contemporary and historic changes in penguin trophic niches and carrying capacity of the Southern Indian Ocean. PLoS ONE 6:e16484 doi:10.1371/journal.pone.0016484 
Jaeger A, Blanchard P, Richard P, Cherel Y (2009) Using carbon and nitrogen isotopic values of body feathers to infer inter- and intra-individual variations of seabird feeding ecology during molt. Mar Biol 156:1233-1240

> Jaeger A, Connan M, Richard P, Cherel Y (2010a) Use of stable isotopes to quantify seasonal changes of trophic niche and levels of population and individual specialisation in seabirds. Mar Ecol Prog Ser 401:269-277

> Jaeger A, Lecompte VJ, Weimerskirch H, Richard P, Cherel Y (2010b) Seabird satellite tracking validates the use of latitudinal isoscapes to depict predators' foraging areas in the Southern Ocean. Rapid Commun Mass Spectrom 24:3456-3460

Jardine TD, Cunjak RA (2005) Analytical error in stable isotope ecology. Oecologia 144:528-533

Käkelä A, Furness RW, Kelly A, Strandberg U, Waldron S, Käkelä R (2007) Fatty acid signatures and stable isotopes as dietary indicators in North Sea seabirds. Mar Ecol Prog Ser 342:291-301

Käkelä R, Käkelä A, Martínez-Abraín A, Sarzo B and others (2010) Fatty acid signature analysis confirms foraging resources of a globally endangered Mediterranean seabird species: calibration test and application to the wild. Mar Ecol Prog Ser 398:245-258

Karnovsky NJ, Kwaśniewski S, Wȩsławski JM, Walkusz W, Beszczyńska-Möller A (2003) Foraging behavior of little auks in a heterogeneous environment. Mar Ecol Prog Ser 253:289-303

Karnovsky NJ, Hobson KA, Iverson S, Hunt GL Jr (2008) Seasonal changes in diets of seabirds in the North Water Polynya: a multiple-indicator approach. Mar Ecol Prog Ser 357:291-299

Kelly JF (2000) Stable isotopes of carbon and nitrogen in the study of avian and mammalian trophic ecology. Can J Zool 78:1-27

Larson K, Craig D (2006) Digiscoping vouchers for diet studies in bill-load holding birds. Waterbirds 29:198-202

> Layman CA, Quattrochi JP, Peyer CM, Allgeier JE (2007) Niche width collapse in a resilient top predator following ecosystem fragmentation. Ecol Lett 10:937-944

Lindsay MCM, Meathrel CA (2008) Where, when and how? Limitations of the techniques used to examine dietary preference of the Pacific gulls (Larus pacificus) using non-consumed parts of prey and regurgitated pellets of prey remains. Waterbirds 31:611-619

> Logan JM, Jardine TD, Miller TJ, Bunn SE, Cunjak RA, Lutcavage ME (2008) Lipid corrections in carbon and nitrogen stable isotope analyses: comparison of chemical extraction and modeling methods. J Anim Ecol 77: 838-846

> Lorrain A, Graham B, Menard F, Popp B, Bouillon S, van Breugel P, Cherel Y (2009) Nitrogen and carbon isotope values of individual amino acids: a tool to study foraging ecology of penguins in the Southern Ocean. Mar Ecol Prog Ser 391:293-306

> Louzao M, Navarro J, Forero MG, Igual JM, Genovart M, Hobson KA, Oro D (2011) Exploiting the closest productive area: geographical segregation of foraging grounds in a critically endangered seabird. Mar Ecol Prog Ser 429:291-301

> MacKenzie KM, Palmer MR, Moore A, Ibbotson AT, Beaumont WRC, Poulter DJS, Trueman CN (2011) Locations of marine animals revealed by carbon isotopes. Sci Rep 1: Article 21 doi:10.1038/srep00021

- Maranto C, Parrish JK, Herman DP, Punt AE, Olden JD,
Brett MT, Roby DD (2011) Use of fatty acid analysis to determine dispersal of Caspian terns in the Columbia River basin. Conserv Biol 25:736-746

> Martínez del Rio C, Anderson-Sprecher R (2008) Beyond the reaction progress variable: the meaning and significance of isotopic incorporation data. Oecologia 156:765-772

> Martínez del Rio C, Wolf N, Carleton SA, Gannes LZ (2009) Isotopic ecology ten years after a call for more laboratory experiments. Biol Rev Camb Philos Soc 84:91-111

> McClelland JW, Montoya JP (2002) Trophic relationships and the nitrogen isotopic composition of amino acids in phytoplankton. Ecology 83:2173-2180

McDaniel JD, Emslie SD (2002) Fluctuations in Adélie penguin prey size in the mid to late Holocene, northern Marguerite Bay, Antarctic Peninsula. Polar Biol 25:618-623

Michener RH, Schell DM (1994) Stable isotope ratios as tracers in marine aquatic food webs. In: Lajtha K, Michener RH (eds) Stable isotopes in ecology and environmental science. Blackwell, London, p 138-157

Miller AK, Karnovsky NJ, Trivelpiece WZ (2009) Flexible foraging strategies of gentoo penguins Pygoscelis papua over 5 years in the South Shetland Islands, Antarctica. Mar Biol 156:2527-2537

Minami H, Ogi H (1997) Determination of migratory dynamics of the sooty shearwater in the Pacific using stable carbon and nitrogen isotope analysis. Mar Ecol Prog Ser 158:249-256

Montoya JP (2007) Natural abundance of ${ }^{15} \mathrm{~N}$ in marine planktonic ecosystems. In: Michener R, Lajtha K (eds) Stable isotopes in ecology and environmental science. Blackwell, London, p 176-201

> Moore JW, Semmens BX (2008) Incorporating uncertainty and prior information into stable isotope mixing models. Ecol Lett 11:470-480

> Moreno R, Jover L, Munilla I, Velando A, Sanpera C (2010) A three-isotope approach to disentangling the diet of a generalist consumer: the yellow-legged gull in northwest Spain. Mar Biol 157:545-553

Neves VC, Nolf D, Clarke MR (2011) Diet of Bulwer's petrel (Bulweria bulwerii) in the Azores, NE Atlantic. Waterbirds 34:357-362

Newsome SD, Martínez del Rio C, Bearhop S, Phillips DL (2007) A niche for isotopic ecology. Front Ecol Environ 5: 429-436

> Norris DR, Arcese P, Preikshot D, Bertram DF, Kyser TK (2007) Diet reconstruction and historic population dynamics in a threatened seabird. J Appl Ecol 44:875-884

> Oppel S, Federer RN, O'Brien DM, Powell AN, Hollmen TE (2010) Effect of lipid extraction on stable isotope ratios in avian egg yolk: is arithmetic correction a reliable alternative? Auk 127:72-78

Owens NJP (1987) Natural variations in ${ }^{15} \mathrm{~N}$ in the marine environment. Adv Mar Biol 24:389-451

Parnell AC, Inger R, Bearhop S, Jackson AL (2010) Source partitioning using stable isotopes: coping with too much variation. PLoS ONE 5:e9672 doi:10.1371/journal.pone. 0009672

> Pearson DL, Hamilton AL, Erwin TL (2011) Recovery plan for the endangered taxonomy profession. Bioscience 61 : 58-63

> Pearson TH (1968) The feeding biology of sea-bird species breeding on the Farne Islands, Northhumberland. J Anim Ecol 37:521-552

> Peterson BJ, Fry B (1987) Stable isotopes in ecosystem studies. Annu Rev Ecol Syst 18:293-320 
Phillips DL, Gregg JW (2003) Source partitioning using stable isotopes: coping with too many sources. Oecologia 136:261-269

Phillips DL, Koch PL (2002) Incorporating concentrationdependence in stable isotope mixing models. Oecologia 130:114-125

Phillips RA, Bearhop S, McGill RAR, Dawson DA (2009) Stable isotopes reveal individual variation in migration strategies and habitat preferences in a suite of seabirds during the nonbreeding period. Oecologia 160:795-806

Phillips RA, McGill RAR, Dawson DA, Bearhop S (2011) Sexual segregation in distribution, diet and trophic level of seabirds: insights from stable isotope analysis. Mar Biol 158:2199-2208

> Piche J, Iverson SJ, Parrish F (2010) Characterization of forage fish and invertebrates in the Northwestern Hawaiian Islands using fatty acid signatures: species and ecological groups. Mar Ecol Prog Ser 418:1-15

Point D, Sonke JE, Day RD, Roseneau DG and others (2011) Methylmercury degradation influenced by sea-ice cover in northern high-latitude marine ecosystems. Nat Geosci 4:188-194 DOI: 10.1038/NGEO1049

> Polito MJ, Fisher S, Tobias CR, Emslie SD (2009) Tissuespecific isotopic discrimination factors in gentoo penguin (Pygoscelis papua) egg components: implications for dietary reconstruction using stable isotopes. J Exp Mar Biol Ecol 372:106-112

> Polito MJ, Trivelpiece WZ, Karnovsky NJ, Ng E, Patterson WP, Emslie SD (2011) Integrating stomach content and stable isotope analyses to quantify the diets of pygoscelid penguins. PLoS ONE 6:e26642 doi:10.1371/journal.pone. 0026642

Popp BN, Graham BS, Olson RJ, Hannides CCS and others (2007) Insight into the trophic ecology of yellowfin tuna, Thunnus albacares, from compound-specific nitrogen isotope analysis of proteinaceous amino acids. In: Dawson TE, Siegwolf RTW (eds) Stable isotopes as indicators of ecological change. Academic Press, New York, NY, p 173-190

> Post DM (2002) Using stable isotopes to estimate trophic position: models, methods and assumptions. Ecology 83: 703-718

> Post DM, Layman CA, Arrington DA, Takimoto G, Quattrochi J, Montana CG (2007) Getting to the fat of the matter: models, methods and assumptions for dealing with lipids in stable isotope analyses. Oecologia 152:179-189

Qi H, Coplen T, Wassenaar LI (2011) Improved online $\delta^{18} \mathrm{O}$ measurements of nitrogen- and sulfur-bearing organic materials and a proposed analytical protocol. Rapid Commun Mass Spectrom 25:2049-2058

> Quillfeldt P, McGill RAR, Furness RW (2005) Diet and foraging areas of Southern Ocean seabirds and their prey inferred from stable isotopes: review and case study of Wilson's storm-petrel. Mar Ecol Prog Ser 295:295-304

> Quillfeldt P, McGill RAR, Strange IJ, Masello JF, Weiss F, Brickle P, Furness RW (2008) Stable isotope analysis reveals sexual and environmental variability and individual consistency in foraging of thin-billed prions. Mar Ecol Prog Ser 373:137-148

> Quillfeldt P, Voigt CC, Massello JF (2010) Plasticity versus repeatability in seabird migratory behavior. Behav Ecol Sociobiol 64:1157-1164

Ramos R, Gonzalez-Solis J, Ruiz X (2009a) Linking isotopic and migratory patterns in a pelagic seabird. Oecologia 160:97-105
Ramos R, Gonzalez-Solis J, Croxall JP, Oro D, Ruiz X (2009b) Understanding oceanic migrations with intrinsic biogeochemical markers. PLoS ONE 4:e6236 doi: 10.1371/journal.pone.0006236

Ramos R, Ramirez F, Carrasco JL, Jover L (2011) Insights into the spatiotemporal component of feeding ecology: an isotopic approach for conservation management sciences. Divers Distrib 17:338-349

Rayner MJ, Hartill BW, Hauber ME, Phillips RA (2010) Central place foraging by breeding Cook's petrel Pterodroma cookii: foraging duration reflects range, diet and chick meal mass. Mar Biol 157:2187-2194

Reinalda LH, Zamon JE, Philips EM (2010) The use of digital imagery to improve training, accuracy, and efficiency in seabird diet analysis. 1st World Seabird Conf, Sept. 7-11, 2010 Victoria, British Columbia, Canada. Abstract

> Richoux N, Jauquemt S, Bonnevie B, Cherel Y, McQuai C (2010) Trophic ecology of grey-headed albatrosses from Marion Island, Southern Ocean: insights from stomach contents and diet tracers. Mar Biol 157:1755-1766

> Robbins CT, Felicetti NA, Sponheimer M (2005) The effect of dietary protein quality on nitrogen isotope discrimination in mammals and birds. Oecologia 144:534-540

Robertson G, Kent S, Seddon J (1994) Effects of the wateroffloading technique on Adélie penguins. J Field Ornithol 65:376-380

Roby DD, Brink KL, Place AR (1989) Relative passage rates of lipid and aqueous digesta in the formation of stomach oils. Auk 106:303-313

> Ronconi RA, Koopman HN, McKinstry CAE, Wong SNP, Westgate AJ (2010) Inter-annual variability in diet of non-breeding pelagic seabirds Puffinus spp. at migratory staging areas: evidence from stable isotopes and fatty acids. Mar Ecol Prog Ser 419:267-282

> Roscales JL, Gómez-Díaz E, Neves V, González-Solís J (2011) Trophic versus geographic structure in stable isotope signatures of pelagic seabirds breeding in the northeast Atlantic. Mar Ecol Prog Ser 434:1-13

Rubenstein DR, Hobson KA (2004) From birds to butterflies: animal movement patterns and stable isotopes. Trends Ecol Evol 19:256-263

Sanpera C, Valladares S, Moreno R, Ruiz X, Jover L (2008) Assessing the effects of the Prestige oil spill on the European shag (Phalacrocorax aristotelis): trace elements and stable isotopes. Sci Total Environ 407:242-249

Schaffner FC, Swart PK (1991) Influence of diet and environmental water on the carbon and oxygen isotopic signature of eggshell carbonate. Bull Mar Sci 48:23-38

> Schell DM, Barnett BA, Vinette KA (1998) Carbon and nitrogen isotope ratios in zooplankton of the Bering, Chukchi and Beaufort seas. Mar Ecol Prog Ser 162:11-23

> Sears J, Hatch SA, O'Brien DM (2009) Disentangling effects of growth and nutritional status on seabird stable isotope ratios. Oecologia 159:41-48

> Shealer DA (1998) Difference in diet and chick provisioning between adult roseate and Sandwich terns in Puerto Rico. Condor 100:131-140

Spear LB, Ainley DG, Walker WA (2007) Foraging dynamics of seabirds in the Eastern Tropical Pacific Ocean. Stud Avian Biol 35:1-99

> Springer AM, Byrd GV, Iverson SJ (2007) Hot oceanography: planktivorous seabirds reveal ecosystem responses to warming of the Bering Sea. Mar Ecol Prog Ser 352: 289-297 
Stewart C (2005) Inference on the diet of predators using fatty acid signatures. PhD thesis, Dalhousie University, Halifax, NS

Stewart REA, Outridge PM (2003) Walrus life history movements reconstructed from lead isotopes in annual layers of teeth. Mar Mamm Sci 19:806-818

Thompson DR, Phillips RA, Stewart FM, Waldron S (2000) Low $\delta^{13} \mathrm{C}$ signatures in pelagic seabirds: lipid ingestion as a potential source of ${ }^{13} \mathrm{C}$-depleted carbon in the Procellariiformes. Mar Ecol Prog Ser 208:265-271

Tollit DJ, Pierce GJ, Hobson KA, Bowen WD, Iverson SJ (2010) Diet. In: Boyd IL, Bowen WD, Iverson SJ (eds) Marine mammal ecology and conservation: a handbook of techniques. Oxford University Press, Oxford, p 191-221

Van Heezik YK, Seddon P (1989) Stomach sampling in the yellow-eyed penguin: erosion of otoliths and squid beak. J Field Ornithol 60:451-458

> Vanderklift MA, Ponsard S (2003) Sources of variation in consumer-diet $\delta^{15} \mathrm{~N}$ enrichment: a meta-analysis. Oecologia 136:169-182

Volkman NJ, Presler P, Trivelpiece WZ (1980) Diets of Pygoscelis penguins at King George Island, Antarctica. Condor 82:373-378

Votier SC, Bearhop S, Witt MJ, Inger R, Thompson $\mathrm{D}$, Newton J (2010) Individual responses of seabirds to commercial fisheries revealed using GPS tracking, stable isotopes and vessel monitoring systems. J Appl Ecol 47: 487-497

Wang SW, Iverson SJ, Springer AM, Hatch SA (2007) Fatty acid signatures of stomach oil and adipose tissue of northern fulmars (Fulmarus glacialis) in Alaska: implications for diet analysis of Procellariiform birds. J Comp Physiol B Biochem Syst Environ Physiol 177:893-903

Wang SW, Iverson SJ, Springer AM, Hatch SA (2009) Spatial and temporal diet segregation in northern fulmars Fulmarus glacialis breeding in Alaska: insights from fatty

Submitted: August 31, 2011; Accepted: March 8, 2012 acid signatures. Mar Ecol Prog Ser 377:299-307

> Wang SW, Hollmen TE, Iverson SJ (2010) Validating quantitative fatty acid signature analysis (QFASA) to estimate diets of threatened spectacled and Steller's eiders (Somateria fischeri and Polysticta stelleri). J Comp Physiol B Biochem Syst Environ Physiol 180:125-139

West JB, Bowen GJ, Dawson TE, Tu KP (2010) Isoscapes: understanding movements, pattern and process on Earth through isotope mapping. Springer, New York, NY

> Williams CT, Buck CL, Sears J, Kitaysky AS (2007) Effects of nutritional restriction on nitrogen and carbon stable isotopes in growing seabirds. Oecologia 153:11-18

Williams CT, Iverson SJ, Buck CL (2008) Stable isotopes and fatty acid signatures reveal age- and stage-dependent foraging niches in tufted puffins. Mar Ecol Prog Ser 363: 287-298

> Williams CT, Iverson SJ, Buck CL (2009) The effects of diet and caloric restriction on adipose tissue fatty acid signatures of tufted puffin (Fratercula cirrhata) nestlings. J Comp Physiol B Biochem Syst Environ Physiol 179: 711-720

Wilson RP (1984) An improved stomach pump for penguins and other seabirds. J Field Ornithol

Wolf N, Carleton SA, Martínez del Rio C (2009) Ten years of experimental animal isotope ecology. Funct Ecol 23: $17-26$

> Woo KJ, Elliott KH, Davidson M, Gaston AJ, Davoren GK (2008) Individual specialization in diet by generalist marine predator reflects specialization in foraging behavior. J Anim Ecol 77:1082-1091

Xavier JC, Cherel Y (2009) Cephalopod beak guide for the Southern Ocean. British Antarctic Survey, Cambridge

> Xavier JC, Phillips RA, Cherel Y (2011) Cephalopods in marine predator diet assessments: why identifying upper and lower beaks is important. ICES J Mar Sci 68: 1857-1864

Proofs received from author(s): April 5, 2012 